\title{
Clothing-Mediated Exposures to Chemicals and Particles
}

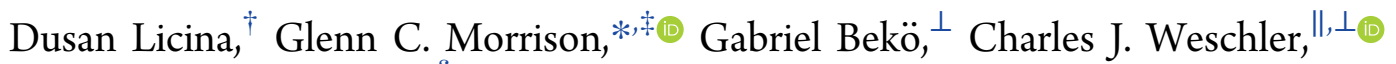 \\ and William W. Nazaroff ${ }^{\S}$ \\ ${ }^{\dagger}$ Human-Oriented Built Environment Lab, School of Architecture, Civil and Environmental Engineering, École Polytechnique \\ Fédérale de Lausanne, CH-1015 Lausanne, Switzerland \\ ${ }^{\ddagger}$ Department of Environmental Sciences and Engineering, Gillings School of Global Public Health, The University of North Carolina \\ at Chapel Hill, Chapel Hill, North Carolina 27599, United States \\ ${ }^{\perp}$ International Centre for Indoor Environment and Energy, Department of Civil Engineering, Technical University of Denmark, \\ Lyngby 2800, Denmark \\ "Environmental and Occupational Health Sciences Institute, Rutgers University, Piscataway, New Jersey 08901, United States \\ ${ }^{\S}$ Department of Civil and Environmental Engineering, University of California, Berkeley, California 94720-1710, United States
}

ABSTRACT: A growing body of evidence identifies clothing as an important mediator of human exposure to chemicals and particles, which may have public health significance. This paper reviews and critically assesses the state of knowledge regarding how clothing, during wear, influences exposure to molecular chemicals, abiotic particles, and biotic particles, including microbes and allergens. The underlying processes that govern the acquisition, retention, and transmission of clothing-associated contaminants and the consequences of these for subsequent exposures are explored. Chemicals of concern have been identified in clothing, including byproducts of their manufacture and chemicals that adhere to clothing during use and care. Analogously, clothing acts as a reservoir

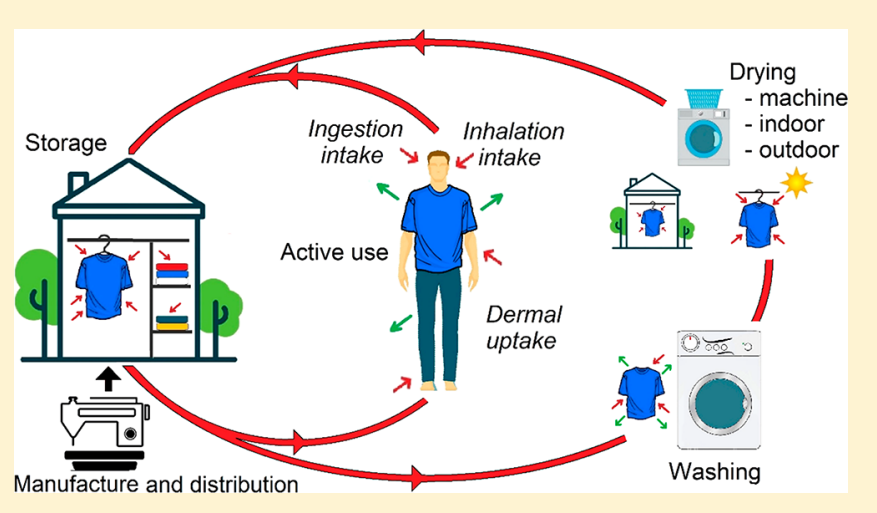
for biotic and abiotic particles acquired from occupational and environmental sources. Evidence suggests that while clothing can be protective by acting as a physical or chemical barrier, clothing-mediated exposures can be substantial in certain circumstances and may have adverse health consequences. This complex process is influenced by the type and history of the clothing; the nature of the contaminant; and by wear, care, and storage practices. Future research efforts are warranted to better quantify, predict, and control clothing-related exposures.

\section{INTRODUCTION}

Diverse chemicals, particles, and microbes are found on clothing. Some are present at the time clothing is purchased, and some are acquired during the care, storage, and use of garments. People spend most of their lives in intimate contact with clothing. They are exposed to the species found on and in their clothing via inhalation, ingestion, and dermal absorption (Figure 1). More specifically, humans inhale species that desorb or are released from their clothing, ingest clothingassociated chemicals and particles when clothing materials enter their mouths, and acquire species on their skin from the clothing they wear. Once in the lungs, in the gastrointestinal system, or on the skin, chemicals from clothing may be absorbed into the body. ${ }^{1}$ As we show in this review, the resulting exposures are influenced by factors inherent to clothing such as fiber type, weave, morphology, dyeing process, color, and chemical treatment (including incorporation of flame retardants, stain repellants, and antiwrinkle agents). Exposures are also influenced by external factors such as washing, drying, storage, and usage patterns. Clothingmediated exposures can contribute to irritation, allergic reactions, and infections as well as risks for adverse health effects as diverse as cancer, birth defects, and heavy-metal poisoning. $^{2-4}$

Studies related to clothing-mediated exposures have been conducted by a diverse set of researchers in the textile industry, government laboratories, and academia., ${ }^{2,3,6}$ While many results have been summarized in reviews, government reports, and books, the findings have yet to be summarized within a framework that focuses on the ways in which clothing mediates exposures to chemicals and particles. This review aims to provide a critical summary from such a perspective. We present the review in two main sections, considering clothing-mediated exposures first to chemicals and second to biotic and abiotic particles. Within these sections, we summarize evidence for the influence of clothing on exposure to chemicals (Section 2.1) and particles (Section 3.1). We review the occurrence and

Received: January 13, 2019

Revised: April 24, 2019

Accepted: April 29, 2019

Published: April 29, 2019 


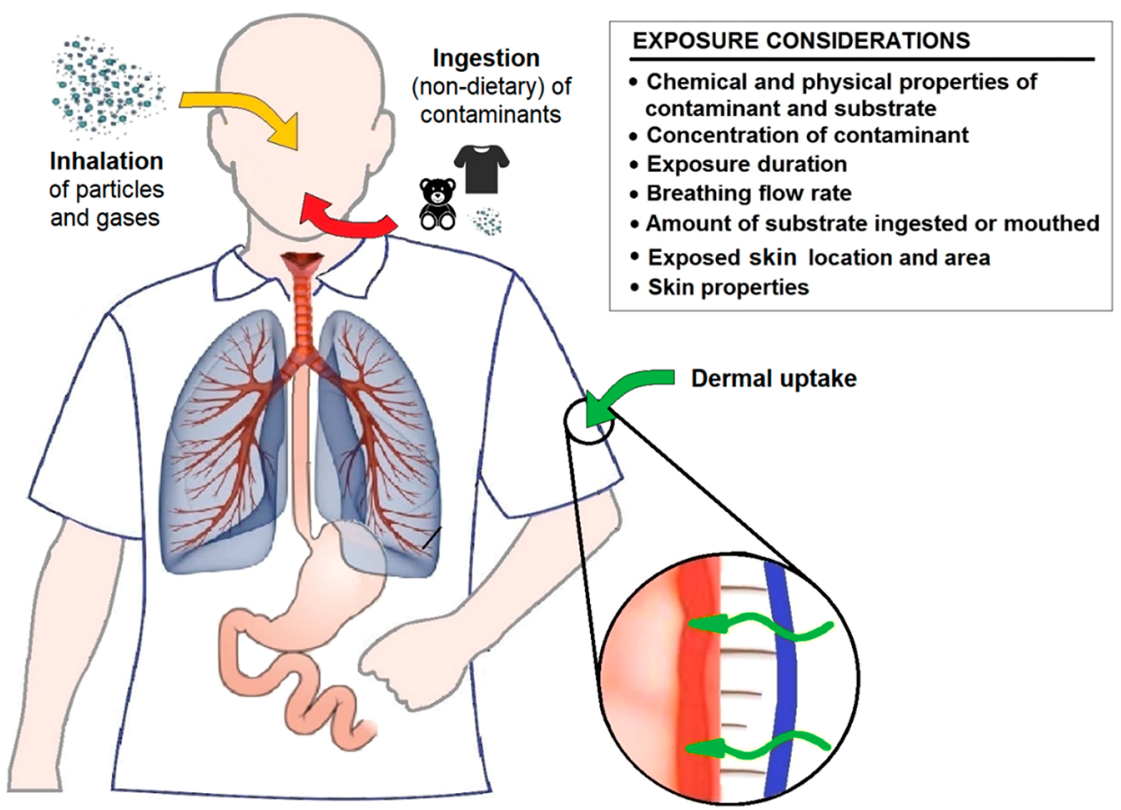

Figure 1. Nondietary routes of human exposure for contaminants of concern: inhalation, ingestion, and dermal absorption.

persistence of chemicals in clothing (Section 2.2), outline a framework for quantifying clothing-mediated particle exposures (Section 3.2), discuss mechanisms of accumulation and transfer of chemicals (Section 2.3), and review factors that influence clothing-associated exposures to particles (Section 3.3). We discuss situations where the underlying factors influencing chemical and particle exposures are similar while also recording fundamental ways that they differ. Whereas the potential influence on health risks is the key ultimate reason to better understand clothing-mediated exposures, a detailed examination to quantify clothing-associated health risks is beyond the scope of this review. We conclude (Section 4) with an examination of knowledge gaps that currently limit the ability to predict or mitigate clothing-related exposures to chemicals and particles. We suggest some research directions that could reduce these limitations. Overall, we find that the influence of clothing on environmental exposures is often substantial, and so additional research efforts are warranted to better understand how clothing influences human exposures and ultimately human health and well-being.

\section{CHEMICAL EXPOSURES}

2.1. Evidence of Clothing-Associated Exposure to Chemicals. 2.1.1. Clothing-Associated Chemicals in Skin, Blood, and Urine. Human exposure and uptake of organic compounds by means of transfer from treated fabrics has been investigated for several decades. For example, in the late 1970s, Blum et al. ${ }^{7}$ reported finding metabolites of the flame retardant tris(2,3-dibromopropyl)phosphate (tris) in the urine of children who had worn clothing treated with this chemical. Radiolabeled tris in treated and dried cloth was shown to penetrate clipped skin of rabbits. Moistening the cloth with simulated sweat did not increase absorption. ${ }^{8}$ Earlier, Armstrong et al. $^{9}$ and Brown ${ }^{10}$ reported instances of infant poisoning attributable to use of phenolic disinfectants in improperly laundered hospital fabrics. Recently, forestry workers wearing permethrin-treated, tick-proof pants were shown to have significantly elevated levels of a permethrin metabolite in their urine. ${ }^{11}$ Moreover, absorption of ethylene oxide (a fumigant), glyphosate (an herbicide), malathion (an insecticide), and benzothiazole (used as dye, biocide, herbicide, and fungicide) from fabric into skin or a skinmimicking membrane has been demonstrated in studies using an in vitro diffusion cell. ${ }^{12-14}$

Measurements of polychlorinated dibenzo- $p$-dioxins and dibenzofurans (PCDD/F) in the stratum corneum, epidermis, and subcutis of eight volunteers as well as in a variety of new fabric swatches showed that some textiles are contaminated and can be an important source of exposure to these chemicals. ${ }^{15}$ The PCDD/F species were shown to diffuse through the stratum corneum into the deeper layers of the skin. Stratum corneum concentrations were substantially higher after wearing contaminated shirts rather than uncontaminated shirts. Skin contamination was heterogeneous, both among individuals and among sites on the same individual. However, when identical, homogeneously contaminated T-shirts were used in a companion study, relatively little spatial and interpersonal variability was observed. ${ }^{16}$ Uptake from polyester was found to be an order of magnitude lower than from cotton. Wearing fabrics that were previously worn enhanced transfer. Residual sweat and lipid compounds may have served as transfer vehicles or possibly weakened the binding interaction between the fabric and PCDD/F. Heavy perspiration during intense physical activity also increased the migration rate of a textile dye, Dianix, onto the skin of volunteer subjects, while contact time was found to be less important. $^{17}$

Clothing can act as a means of transporting pollutants from one environment to another. This phenomenon has been studied in the context of health concerns related to "paraoccupational" exposures. Certain hazardous chemicals such as lead, beryllium, polychlorinated biphenyls (PCB), and pesticides can be transferred from a work site to the worker's home via clothing and thereby contribute to elevated levels in the blood and urine or even to direct adverse health effects. ${ }^{18-20}$ For example, women who laundered agricultural work clothes had up to $42 \%$ higher serum levels of dichlorodiphenyltrichloroethane (DDT) and hexachloroben- 


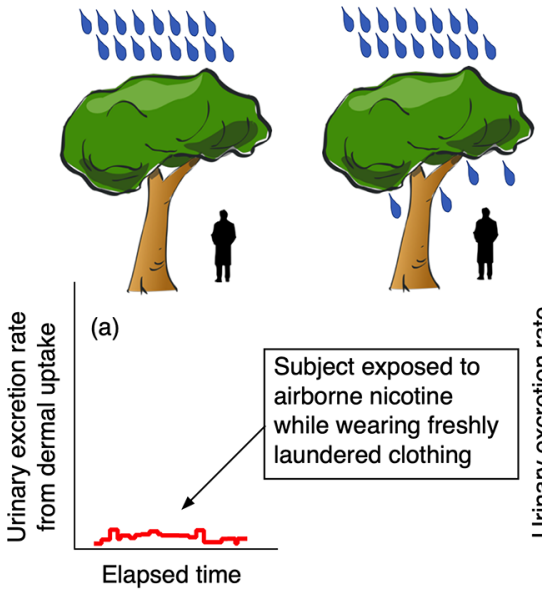

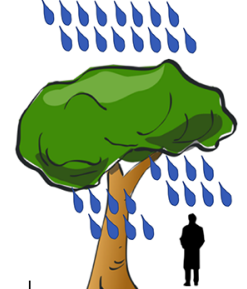

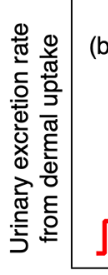

(b)

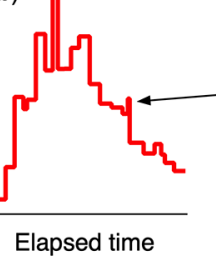

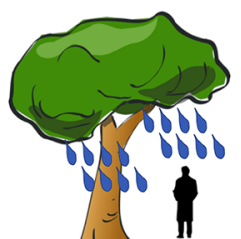

Subject wearing

clothing that had

been exposed to

nicotine

Figure 2. Dynamic urinary excretion rates due to dermal uptake for nicotine and two urinary metabolites (summed) after exposing participants, who were wearing breathing hoods, to airborne nicotine. ${ }^{29}$ (a) Freshly laundered clothing, unexposed to nicotine, is protective; this is analogous to a tree at the beginning of a rainstorm that protects a person from getting wet. (b) Clothing that has been previously exposed to airborne nicotine dramatically increases urinary excretion rate for days after wearing the clothing, just as a standing under tree after a long rainstorm is most certain to get the person wet. This exposure occurs while wearing the clothes in the environment containing the contaminant (third tree from left) and can continue after leaving this environment.

zene compared to women who did not. ${ }^{21,22}$ Similarly, women living in homes in which agricultural workers wore their work clothes had higher levels of most of the organochlorine pesticides that were being used. ${ }^{22}$ Multivariate analyses by Park et al. ${ }^{23}$ indicated an association between serum levels of polybrominated diphenyl ethers in California firefighters and the storage and cleaning practices used for protective gear. The authors suggested that these flame retardants can be transported to fire stations via fireborne dust on soiled turnout gear and that good housekeeping practices can reduce subsequent exposure (see also Section 3.1.4).

2.1.2. Influence of Clothing on Dermal Uptake of Airborne Chemicals. Until recently, the influence of clothing on dermal uptake of airborne organic compounds received relatively little attention. Initial studies examined a few chemicals, primarily volatile organic compounds in occupational settings. Piotrowski ${ }^{24}$ found that clothing reduced dermal uptake of airborne nitrobenzene by about $20-30 \%$, but that clothing had no observable effect on phenol absorption. ${ }^{25}$ Recent efforts have addressed dermal exposures to semivolatile organic compounds common in everyday indoor settings. For example, Morrison et al. ${ }^{26}$ measured the uptake of two airborne phthalates, diethyl phthalate (DEP) and di-n-butyl phthalate (DnBP), by an individual wearing either clean clothes or clothes previously air-exposed in a chamber with elevated phthalate concentrations. When compared with dermal uptake for bare-skinned individuals under otherwise identical experimental conditions, ${ }^{27}$ clean clothes decreased transdermal uptake by factors of 3-6, whereas previously exposed clothes increased dermal uptake by factors of 3 and 6 for DEP and DnBP, respectively. Analogous results were obtained for nicotine. ${ }^{28,29}$ This role of clothing as either "protector" or "amplifier" of dermal uptake is illustrated in Figure 2. In another study, three subjects exhibited elevated urinary excretion rates of the UV filter benzophenone-3 (BP-3) and its metabolite benzophenone-1 shortly after donning $\mathrm{T}$ shirts previously exposed to air with elevated BP-3 levels. ${ }^{30}$ The authors suggested that dermal uptake of BP-3 from clothing could meaningfully contribute to overall body burdens.
The protective effect of uncontaminated clothing has also been indicated by reduced phthalate and halogenated flame retardant concentrations in skin wipe samples taken from body parts covered with clothing compared to uncovered skin. ${ }^{31,32}$ However, clothing did not provide total protection in these studies. In vitro experiments demonstrated reduced absorption of organophosphates through a cotton shirt as compared to unclothed skin. ${ }^{33}$ However, common clothing is reported to have little effect on dermal exposure to certain gases in hazardous material incidents such as methyl bromide, sulfuryl fluoride, chloropicrin, and ethylene oxide. ${ }^{34,35}$

2.1.3. Health Effects As Evidence of Exposure. Studies of health effects related to hazardous substances in textiles further suggest clothing-associated exposures. These works have mainly focused on dermatitis caused by textile dyes and finishing resins. ${ }^{36-41}$ A limited literature also exists on carcinogenic, mutagenic, and reprotoxic substances in textile articles. These effects have been suggested for certain dyes, especially azo dyes, ${ }^{42-45}$ and for some antibacterial agents such as triclosan. ${ }^{46,47}$ Brominated flame retardants, phthalates, and degradation products of highly fluorinated polymeric water repellents and stain repellents, which can be present in textile articles, have been associated with reproductive and developmental toxicity. ${ }^{48-52}$ Evidence of direct health effects of such clothing-related exposures is lacking. Comprehensive reviews of textile-related health studies can be found in the Swedish Chemicals Agency's report ${ }^{3}$ and in the opinion statement of the German Federal Institute for Risk Assessment. $^{2}$

2.2. Occurrence, Persistence, and Accumulation of Chemicals in Clothing. The chemicals present in clothing are a mix of those present at the time of purchase (possibly attenuating with time) and those acquired postpurchase. This mix changes with cleaning practices, storage, and wear.

2.2.1. Chemicals Present at Time of Purchase. Most of the chemicals that have been measured in clothing at the time of purchase are a consequence of manufacturing processes (e.g., dyeing, bleaching, finishing) or have been deliberately added and are intended to be retained during the life of the garment. The latter group, referred to as "auxiliaries", includes 
antiwrinkling resins, flame retardants, antimicrobial agents, pesticides, surfactants, and other coating chemicals. Dyeing involves the largest range of chemicals with an estimated 800 dyes currently in use. ${ }^{2}$ A move toward more environmentally benign textile dyeing is altering the mix of chemicals used in dyeing. ${ }^{53}$ Some chemicals in clothing fabrics are present as a consequence of packaging, transport, storage, and other processes that occur between manufacture and purchase.

Chemicals that have been identified on newly purchased clothing include trace elements such as heavy metals; ${ }^{5-62}$ residual aromatic amines associated with certain azo dyes; ${ }^{63,64}$ quinoline and substituted quinolines; ${ }^{65-69}$ alkylphenol ethoxylates, alkylphenols, bisphenols, and benzophenones; ${ }^{70,71}$ benzothiazoles and benzotriazoles, ${ }^{68,72-74}$ dioxins and furans; $^{15}$ PCBs; ${ }^{19,75}$ organo-phosphorus flame retardants and pesticides; ${ }^{76}$ halogenated flame retardants; ${ }^{7,8,77}$ fluorinated surfactants; $^{78-81}$ phthalate ester plasticizers; ${ }^{82,83}$ glycol solvents; $^{84}$ formaldehyde from antiwrinkle resins; $;^{40,41,85,86}$ and common petrochemical fuel constituents such as linear and branched $\mathrm{C}_{10}-\mathrm{C}_{16}$ alkanes, $\mathrm{C}_{3}$ alkylbenzenes, and straightchained $\mathrm{C}_{7}-\mathrm{C}_{10}$ aldehydes. ${ }^{87}$

Relatively new chemical analysis techniques are being applied to assess chemicals in clothing. Antal et al. ${ }^{65}$ described the use of direct analysis in real-time (DART) mass spectrometry to measure more than 40 chemicals in clothing items, including alkylphenol ethoxylates, phthalate esters, alkyl amines, aniline, pyridine, quinoline, and substituted quinoline. In a recent review, Rovira and Domingo ${ }^{4}$ reported on chemicals that have a high probability of being detected on clothing, with a focus of the health risks posed by these species. Of special note are extensive government reports from Denmark, ${ }^{84}$ The Netherlands, ${ }^{5}$ Germany, ${ }^{2}$ and Sweden ${ }^{3}$ that review and critically discuss chemicals found in clothing, especially the chemicals that may be present at the time of purchase.

2.2.2. Chemicals Acquired Postpurchase. Chemicals present in air, especially indoor air, can also be present on clothing exposed to that air. ${ }^{30,88-95}$ A commonly encountered example of chemical uptake from air occurs when clothing is exposed to environmental tobacco smoke (ETS). Up to a milligram of nicotine can be sorbed by a square meter of cotton fabric during just a few hours of exposure. ${ }^{96}$ Odors derived from ETS constituents can linger on clothing for hours to days. More generally, how much or how little of a chemical is transferred from air to clothing depends on several factors. One key factor is the partition coefficient between clothing and air $\left(K_{\mathrm{ca}}\right)$ for the fabric in question. As a rule of thumb, the more an airborne chemical resembles the chemical nature of the fabric that constitutes the clothing, the larger is the value of $K_{\mathrm{ca}}$ and consequently the greater is the sorptive partitioning of that chemical to the clothing. The octanol/air partition coefficient $\left(K_{\mathrm{oa}}\right)$ is a good predictor of $K_{\mathrm{ca}}$ for cotton because cotton is cellulosic, for which octanol is a reasonable surrogate. ${ }^{89-91,97}$ Values of $K_{\mathrm{ca}}$ in relation to vapor pressure for several different fiber types have been reported. ${ }^{91}$ Still needed are systematic investigations of $K_{\text {ca }}$ for an array of environmental chemicals to a range of clothing fibers, including wool, polyester, nylon, rayon, and other synthetics as well as blends to better estimate the sorption of airborne chemicals to these fiber types.

Clothing can acquire chemicals while in closets, storage containers, and chests. A well-known example is sorption of the chemical agents used as moth repellants: naphthalene, camphor, and $p$-dichlorobenzene. ${ }^{98,99}$ Similarly, one would anticipate that phthalate esters or alternative plasticizers would be sorbed to clothing stored in polyvinyl chloride (PVC) storage boxes or bags.

Contact with surfaces can transfer chemicals to clothing. Such chemicals can migrate through clothing becoming available for dermal uptake. Personal care products and fragrances applied to the skin or hair can also be transferred to clothing via contact. ${ }^{100,101}$ Clothing can retain certain chemicals transferred from personal care products, exposing the wearer and, in principle, those sharing indoor spaces to such chemicals during storage and during repeat wearings until the item is effectively cleaned.

Laundering and dry-cleaning removes certain chemicals from clothing but can add others. The fraction of a chemical that is removed from clothing during cleaning varies with the nature of the chemical as well as with the cleaning practices, including the detergent or dry-cleaning solvent that is employed. Gong et al. ${ }^{31}$ found that the efficiency with which machine washing removed phthalates from cotton jeans increased with the octanol/water partition coefficient $\left(K_{\mathrm{ow}}\right)$ of the phthalate. During dry-cleaning, clothing can retain chemicals from cleaning solvents that subsequently contribute to personal exposures. ${ }^{102,103}$ During laundering, clothing may acquire scents (e.g., synthetic musks ${ }^{2}$ ) and other detergent constituents (e.g., alkylphenol ethoxylates ${ }^{104}$ ). Following the wash cycle, clothing is either air-dried or mechanically dried. When air-dried, the clothing can sorb chemicals from the air in which it is dried. When mechanically dried, some chemicals can be thermally desorbed while other chemicals (e.g., fabric softeners introduced using "dryer sheets") may be sorbed by the clothing. Laundering also results in chemicals being transferred among the differing items that are washed or dried together. Cross-contamination of fabrics during laundering and storage has been reported for permethrin-treated garments. ${ }^{105}$

Chemicals on clothing can be chemically transformed to other species. Of longstanding concern are the abiotic and microbial reduction of azo dyes to carcinogenic aromatic amines such as aniline, benzidine, and 2-naphthylamine. ${ }^{106-111}$ For example, analysis of 86 textile products purchased in Japan detected aromatic amines at low concentrations in socks, undershorts, pants, and other garments. ${ }^{64}$ Oxidants can also degrade azo dyes, as shown by reactions initiated by the hydroxy radical, generating benzene and substituted benzenes. ${ }^{112}$ Photolytic debromination has been shown to produce low levels of polybrominated dibenzofurans ${ }^{113}$ when clothing containing the flame retardant hexabromocyclodecane (HBCD) is dried in the sun.

During wear, clothing acquires skin oils, whose constituents can be altered via microbial activity. Different fiber types promote the growth of different microbes, influencing malodor generation from microbial metabolism of apocrine and sebaceous secretions. ${ }^{114,115}$ Squalene, a major constituent of skin oil, ${ }^{116}$ has been shown to react with ozone on T-shirts generating products with a range of volatilities. ${ }^{117-119}$ The less volatile products remain on the apparel item, exposing the wearer to species such as $\mathrm{C}_{27}$-pentaenal, $\mathrm{C}_{22}$-tetraenal, $\mathrm{C}_{17^{-}}$ trienal, and their carboxylic acid counterparts. ${ }^{120}$ Squalene also reacts with $\mathrm{HOCl}$, the active ingredient in chlorine bleach, to generate chlorinated squalene products. Three to four chlorine atoms become covalently incorporated into the squalene molecule during a $1 \mathrm{~h}$ exposure to $1 \mathrm{ppb} \mathrm{HOCl}^{121}$ Such 
species may not be fully removed from clothing during washing. More generally, bleach oxidizes chemicals on clothing, increasing the water solubility of the contaminants but perhaps leaving behind oxidized and chlorinated residues. Numerous low volatility oxidation products, starting with primary carbonyls and carboxylic acids and evolving to products with high $\mathrm{O}$ to $\mathrm{C}$ ratios, result when ozone reacts with terpenes or sesquiterpenes transferred to clothing from personal care products. Other examples of chemicals generated via reactions that occur on clothing include nonylphenol, a known endocrine disruptor, from the degradation of nonylphenol ethoxylate detergent residues ${ }^{65}$ and formaldehyde from urea-formaldehyde and melamine/formaldehyde resins used as antiwrinkling agents. ${ }^{40,41,86}$ The potential for chemical transformations to occur on clothing is commonly overlooked during assessments of exposures to environmental chemicals.

2.3. Mechanisms, Quantification, and Prediction of Exposure and Transfer of Chemicals. Clothing influences chemical exposure by a variety of mechanisms, including some that are complex and poorly characterized. Organizations such as the US Environmental Protection Agency, the World Health Organization, and the European Chemicals Agency provide guidance on estimating exposure from consumer articles; ${ }^{122-124}$ however, such recommendations are based on a far-from-complete understanding and are therefore of limited utility in accurately characterizing complex chemical exposures mediated by clothing. Notwithstanding their limitations, these recommendations and models can be combined with stochastic representations of exposure factors and behaviors to estimate population distributions of exposure. ${ }^{125}$

2.3.1. Dermal Transfer and Absorption. Most exposure models of skin contact transfer of chemicals from surfaces are conservative by design, i.e. they account, realistically, for the maximum potential exposure for risk assessment and risk management purposes. Exposure is derived from factors including the skin area in contact; the concentration of the chemical in the material; the number, frequency, or duration of contact events; the type of contact; and transfer efficiency. ${ }^{122,124}$ The transfer efficiency is the fraction of the chemical in the material that transfers during contact events. Experimental measurements of the transfer of pesticides ${ }^{126}$ and fluorescent tracers ${ }^{127}$ from carpet and of permethrin from military uniforms ${ }^{128}$ have been used to quantify transfer efficiency of residues from textiles. Some experimental results used to derive residue transfer efficiency are based on lowvolatility chemicals directly applied to the side of the textile in contact with the skin. Therefore, the residue transfer model may inaccurately characterize exposure from clothing that has volatile or semivolatile chemicals distributed throughout the fabric. Recognizing that diffusive migration can occur within consumer materials, it has been proposed that a transfer efficiency can be derived from the amount that can diffuse from a thin "contact layer" of the material. The thickness of this layer can be specified for consumer products or estimated if diffusion coefficients are known for specific chemicalmaterial combinations. ${ }^{129}$ These models generally do not account for the uptake resistance of skin itself. ${ }^{130}$

Models of sweat-mediated transfer of chemicals from clothing also use a transfer efficiency approach. The leachable fraction is derived from experiments using artificial sweat to extract substances such as dyes ${ }^{17,43}$ and trace elements ${ }^{57}$ (see also Section 3.1.3). Often, the extracted fraction is assumed to be entirely transferred to the skin. Such an approach is likely to overestimate exposures, since only a fraction of the sweat will return to the skin from clothing. For example, Meinke et al. ${ }^{17}$ extracted fluorescent dyes from a polyester/cotton blend shirt using a sweat simulant and compared the predicted exposure (based on $100 \%$ transfer) to that observed in volunteers wearing the shirt during $30 \mathrm{~min}$ of exercise or for $12 \mathrm{~h}$ of normal activity. In these experiments, less than $1 \%$ of the estimated amount of a dye was transferred to volunteers during normal wear or sweating.

Indirect (noncontact) exposure to environmental contaminants can also be influenced by clothing. Clothing has been observed to reduce the transfer of airborne insecticides, ${ }^{131}$ phthalate esters, ${ }^{26}$ and organophosphate flame retardants ${ }^{33}$ to skin. Some models of indirect dermal exposure to airborne contaminants have assumed that clothing is fully permeable. ${ }^{132}$ Other models assume that clothing is fully impermeable. For example, in estimating dermal uptake of polycyclic aromatic hydrocarbons from barbeque fumes to bare skin, Lao et al. ${ }^{88}$ assumed that areas covered by clothing were fully protected. Between these extremes, a mechanistic modeling approach has been introduced that accounts for the history of clothing, contaminant-transfer between clothing and the environment, sorptive partitioning of chemicals to clothing, diffusive and advective transfer through clothing and to skin lipids, as well as resistance to uptake through skin. ${ }^{133,134}$ The clothing component of these models is similar to that used to assess clothing for chemical protection ${ }^{135}$ and can account for uptake through clothing from air as well as exposure to contaminants present in clothing when donned. Predictions using such mechanistic models agree reasonably well with urinary excretion rate measurements for the limited number of human subject studies in which adequate information is available to populate the model parameters. ${ }^{30,134,136}$ These models indicate that clothing can either reduce or increase dermal uptake relative to bare-skin uptake (Figure 2). The extent of exposure is predicted to be sensitive to a chemical's partition coefficient between clothing and air $\left(K_{\mathrm{ca}}\right),{ }^{89-93,137,138}$ the efficiency of chemical removal during laundering, ${ }^{31,68,92,139}$ the air-gap between fabric and skin, laundering frequency, and the history of the clothing items prior to wear. ${ }^{133} \mathrm{~A}$ key advantage of dynamic mechanistic models is that they can predict how clothing accumulates chemicals under nonequilibrium conditions. Such models can be used to derive simpler exposure heuristics for classes of chemicals, types of clothing, and exposure scenarios for risk assessment purposes. 140

2.3.2. Inhalation. Inhalation exposures for clothingassociated chemicals can be modeled using methods similar to those used to estimate inhalation of chemicals emitted by consumer products. For example, the emission rate of drycleaning solvents from clothing hung in a closet can be combined with building air-exchange rates to predict indoor air concentrations, ${ }^{103}$ which are then used to assess inhalation exposures. Inhalation exposure from the emissions that are generated while wearing an article of clothing may be enhanced owing to the "personal cloud" effect, as described for particles in Section 3.1.5. For gaseous pollutants, personalcloud-type alterations have been illustrated in climate chamber experiments investigating transport and pollutant distribution in the breathing zone ${ }^{141}$ as well as using computational fluid dynamics to predict breathing zone concentrations of volatile products that result from ozone reactions with the surface of the body and clothing. ${ }^{142,143}$ For a seated person under typical 
indoor conditions, inhalation exposure to volatile ozone reaction products with skin oils was predicted to be up to 2.5 times higher than the corresponding value for roomaverage concentrations. Predicted exposure to ozone itself was estimated to be $0.6-0.9$ times the corresponding condition for room-average concentrations. ${ }^{142}$ Simulations are currently limited to simple scenarios such as stationary seated or standing individuals. Experimental validation of personal cloud effects for clothing-associated chemical exposures are lacking.

2.3.3. Ingestion. Ingestion by mouthing of fabrics can be a significant exposure pathway, especially for young children. Exposure estimation requires information on the extractability of compounds in saliva, the frequency of mouthing clothing, and the area of the fabric mouthed. Extractability can be quantified using a broader set of in vitro bioavailability methods ${ }^{144}$ which have been applied to determine extractability in saliva simulants of azo dyes ${ }^{145}$ and for silver from nanoparticles. ${ }^{146}$ For highly water-soluble species, upper bounds on exposure can be established by assuming that the chemical is completely extractable. In an evaluation of indirect exposure to environmental airborne methamphetamine in former residential methamphetamine laboratories, mouthing of cotton fabric by toddlers was predicted to generate intakes approximately 10 times greater than all other exposure pathways combined. $^{90}$

A diagrammatic summary of these exposure pathways as influenced by physical-chemical properties is shown in Figure 3. Excepting particles and particle-associated chemicals,

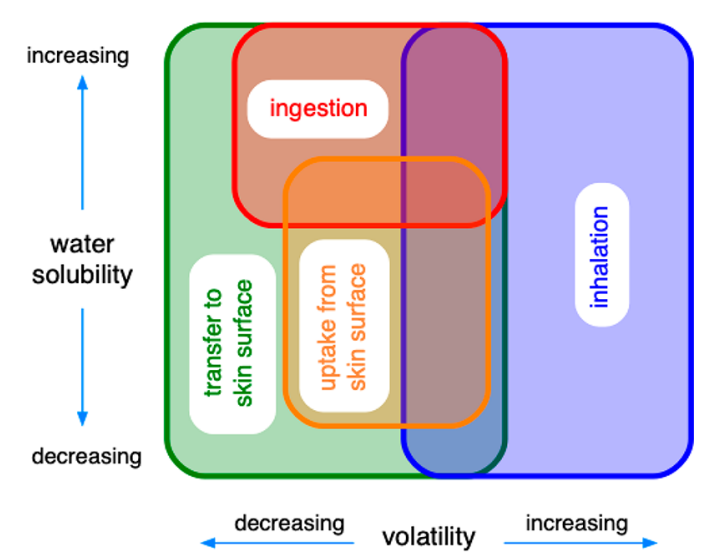

Figure 3. Relative importance of clothing-associated exposure pathways based on a chemical's volatility and water solubility.

inhalation requires a chemical to be volatile enough to become airborne. Ingestion is important for more water-soluble chemicals. Most species can be transferred to skin by contact or transfer through the clothing-skin air gap. For both ingestion and transfer to skin surface, the chemical must be of lower volatility to be present in clothing at meaningful concentrations. Transdermal uptake from the skin surface tends to be highest for chemicals with intermediate volatilities and relatively low water solubilities.

\section{EXPOSURES TO PARTICLES}

3.1. Clothing-Associated Exposures to Biotic and Abiotic Particles. Ample evidence from environmental and occupational exposure studies indicates that clothing can act as an important source of particle-borne agents that contribute to human exposures. Clothing-associated exposures have been observed for biotic and abiotic particles with varied acquisition, retention, and release mechanisms; exposure routes; and potential health outcomes. This section consolidates evidence from relevant empirical and field studies in the context of providing an overview of exposure to biotic and abiotic particles associated with clothing.

3.1.1. Allergens. Exposure to allergenic biological particles from clothing has been well-studied, including cat allergen (Fel d 1), dog allergen (Can d 1), dust mite allergen, and pollens. Tovey et al. ${ }^{147}$ were among the first to identify clothing as a significant source of inhalable allergens. They showed that allergenic dust particles can become resuspended directly from clothing by body movement and can travel to the wearer's breathing zone by means of the thermal plume, thus causing increased allergenic exposures. Other studies found that exposures to mite and cat allergens were closely related to the quantity of particle-bound allergen found on wearer's clothing, suggesting that personal clothing could be an important factor influencing both mite and cat allergen exposure. ${ }^{148,149}$ Evidence of allergen exposure also has been reported for people that are not in direct contact or proximity to any allergenic source. ${ }^{148,150}$ These studies identified clothing as an important indirect exposure vector, transporting particleborne allergens from one space to another.

Much prior evidence concerning clothing-mediated exposures to pet allergens has focused on school environments. ${ }^{151,152}$ Studies have found that allergens can be transported on children's clothing from homes to schools, including both the cat allergen Fel d $1^{148,153}$ and the dog allergen Can $\mathrm{f} 1 .^{154}$ Children without pets can also acquire allergens while in school and subsequently bring them back to their homes. ${ }^{155}$ A study focusing on exposure interventions found that the level of airborne cat allergens in schools could be effectively mitigated either by pet ownership prohibition or by using school uniforms. ${ }^{156}$ Additional evidence has shown that clothing can be a transport vector for the mite allergens Der f 1 and Der p $1^{154,157}$ and for allergenic pollen. ${ }^{158-160}$ Taken together, this body of research persuasively documents that clothing can be an important secondary source of allergenic exposures in buildings, including environments that are free of direct allergenic sources.

3.1.2. Pathogenic Microbes. A second category of clothingrelated biological particles is pathogenic microorganisms that pose threats for the transmission of infectious diseases. Most research about clothing-associated pathogens has focused on health-care settings, owing to concern about hospital-acquired infections. ${ }^{6,161,162}$ Studies have identified pathogenic bacteria on physicians' white coats, ${ }^{163-165}$ neckties, ${ }^{166,167}$ gloves, ${ }^{168}$ nurses' uniforms, ${ }^{169,170}$ and on the coats of medical students. ${ }^{171,172} \mathrm{~A}$ commonly detected pathogen on healthcare apparel is methicillin-resistant Staphylococcus aureus (MRSA). ${ }^{164,165,168,170,173-176}$ Other pathogenic bacteria found on healthcare workers' uniforms have included Clostridium difficile ${ }^{170}$ and vancomycin-resistant Enterococcus (VRE). ${ }^{165,168,170,176}$ In addition to bacterial pathogens, analysis of clothing samples worn by caregivers and visitors has revealed the presence of respiratory syncytial virus, a major cause of respiratory infections among premature infants. ${ }^{177}$

Other studies have provided evidence that links bacterial occurrence in clothing with subsequent exposure. The direct dispersal of Staphylococcus aureus and other bacteria from clothing into air has been identified in operating theaters, ${ }^{178,179}$ isolation wards, ${ }^{180}$ and hospital storage rooms. ${ }^{181}$ Early 
research indicates that pathogen liberation from clothing into air can occur by human movement and by frictional interactions between clothing fibers and skin. ${ }^{178,182-184} \mathrm{~A}$ seminal study by Duguid and Wallace ${ }^{182}$ found that clothing can liberate pathogenic microbes by promoting skin shedding. That same study also showed that sterile, dust-proof fabrics can act as a barrier to the release of skin-associated microbes.

3.1.3. Nanomaterials Associated with Clothing Additives. During the past few decades, embedded nanomaterials have emerged as a class of technological innovations for improving certain features of clothing fabrics such as reducing microbial growth and survival, protecting against ultraviolet radiation, and improving water repellency. To achieve specific targeted functions, prevalent nanostructured clothing additives have included titanium dioxide $\left(\mathrm{TiO}_{2}\right)$, silver, zinc oxide $(\mathrm{ZnO})$, gold, copper, carbon nanotubes, and nanoclays. ${ }^{185}$ An emerging consensus indicates that excessive exposure to nanomaterials can contribute to detrimental health outcomes, including pulmonary inflammation, carcinogenicity, genotoxicity, and circulatory effects. ${ }^{186}$ The effects of nanomaterial additives in clothing on human exposure and consequent health effects remain a subject of debate. Such materials have the potential to be released from clothing fabrics and contribute to exposures of their wearers and others. The mechanisms of release from clothing are different for nanomaterials as compared with biological particles. For example, in addition to mechanical abrasion, nanoparticles can potentially be released from clothing by migrating into human sweat and saliva. ${ }^{146}$

To date, most exposure-related studies have focused on the migration of silver nanoparticles from clothing into human sweat, ${ }^{146,187,188}$ their release during laundering, ${ }^{189,190}$ and their antimicrobial properties. ${ }^{191}$ Dermal exposure to clothingembedded nanoparticles has not been rigorously investigated. One group of studies reported that $\mathrm{TiO}_{2}$ and $\mathrm{ZnO}$ nanoparticles do not penetrate deeply into the skin. ${ }^{192}$ To the contrary, there is evidence of the increase of the ${ }^{68} \mathrm{Zn}$ isotope in the blood of a healthy adult after exposure to ${ }^{68} \mathrm{ZnO}$ nanoparticles in a sunscreen formulation. ${ }^{193}$ One study reported that healthy skin is a more effective barrier for silver nanoparticles than damaged skin. ${ }^{194}$

Overall, there is a need for more research to characterize the influence of antimicrobial agents, including nanoparticles, on microbial diversity in clothing and on the development of microbial resistance over time. Whether the presence of nanomaterials on fabrics in contact with the skin could alter the local skin microbiota remains a key open question.

3.1.4. Paraoccupational Exposures. Studies have reported instances of paraoccupational (or "take-home") exposures to hazardous particles encountered in workplaces. Most such studies have focused on asbestos. As reviewed by Donovan et al. ${ }^{195}$ and Goswami et al., ${ }^{196}$ there is abundant evidence for increased risks of mesothelioma and lung cancer owing to paraoccupational exposure to asbestos fibers and asbestoscontaining dust on workers' clothing. However, relatively little research provides quantitative evidence that mechanistically links workplace encounters with subsequent household exposures. Sahmel et al. ${ }^{197}$ found that handling clothes contaminated with chrysotile asbestos resuspends $0.2-1.4 \%$ of the material. Sanon and Watkins ${ }^{176}$ demonstrated that healthcare uniforms can act as a vector for pathogen transmission outside of hospitals. Overall, the take-home effect for particles and microbial exposure via clothing seems to be a plausible route of transmission worthy of increased attention.

3.1.5. Personal Cloud. An enhancement of inhalation exposure to particles beyond the room-average levels may occur for clothing-associated particle releases. This feature, termed the "personal cloud", was introduced for clothingmediated chemical exposures in Section 2.3.2.

There are multiple dimensions to the clothing-associated personal cloud effect. Key determinants involve size-dependent emission rates of particles from clothing, proximity of clothing to the breathing zone, and local air movement in relation to personal activities. Several studies suggest that direct shedding from clothing surfaces may be a noteworthy source of coarsemode particles and bioaerosols indoors, ${ }^{198-201}$ but none of them quantified contributions to the personal cloud effect. A recent study by Licina et al. ${ }^{202}$ reported that clothing movement can release coarse particles into the perihuman space of a seated person, which can then be transported upward by means of the metabolically induced thermal plume. In that study, the contribution of such releases to the personal cloud was substantial: from 2 to $13 \mu \mathrm{g} / \mathrm{m}^{3}$ in the particle diameter range $1-10 \mu \mathrm{m}$. The contribution of clothingassociated particle release to a personal cloud effect was observed only for seated occupants and specifically not observed during walking. The study suggests that the personal cloud is contingent on physical activities and that manipulating the metabolic thermal plume could alter exposure to clothingreleased particles. Additionally, during more intensive clothing manipulations such as putting on and taking off a shirt or folding and unfolding a shirt, sharp peaks in the breathing zone $\mathrm{PM}_{10}$ mass concentration were detected, at times exceeding 40 $\mu \mathrm{g} / \mathrm{m}^{3}$. Overall, the emerging evidence regarding the personal cloud combined with evidence that clothing can harbor allergens, potentially pathogenic microorganisms, and other harmful substances suggest that clothing surfaces may be an underappreciated factor influencing particle exposure, possibly with public health relevance.

3.2. Toward Quantifying Clothing-Mediated Particle Exposures. The previous section summarized evidence that clothing-mediated exposures to particles are potentially meaningful in diverse circumstances. It is important to characterize exposures quantitatively and, in as far as it is possible, mechanistically, so that one is able to extract generalizable findings from limited experimental evidence. In this section, we outline a framework that could guide and support systematic knowledge acquisition for better understanding how clothing influences inhalation exposures to biotic and abiotic particles.

The central element in this framework is the determination of size-resolved and composition specific emission rates of particles associated with clothing. Such emission rates can be expressed in terms of particle mass per time or particle number per time. Composition is key in relation to health outcomes of concern: allergenic particles, infectious microbes, and abiotic particles each contribute to increased yet distinct adverse health risks.

For known clothing-associated particle emission rates, contributions to exposures can be assessed. For example, particle emission rates from clothing can be incorporated into material balance models to estimate the component of exposure associated with increased indoor air concentrations. ${ }^{203}$ Alternatively, the intake fraction approach can be applied to estimate mass or particle number inhalation 
PARTICLE SOURCE

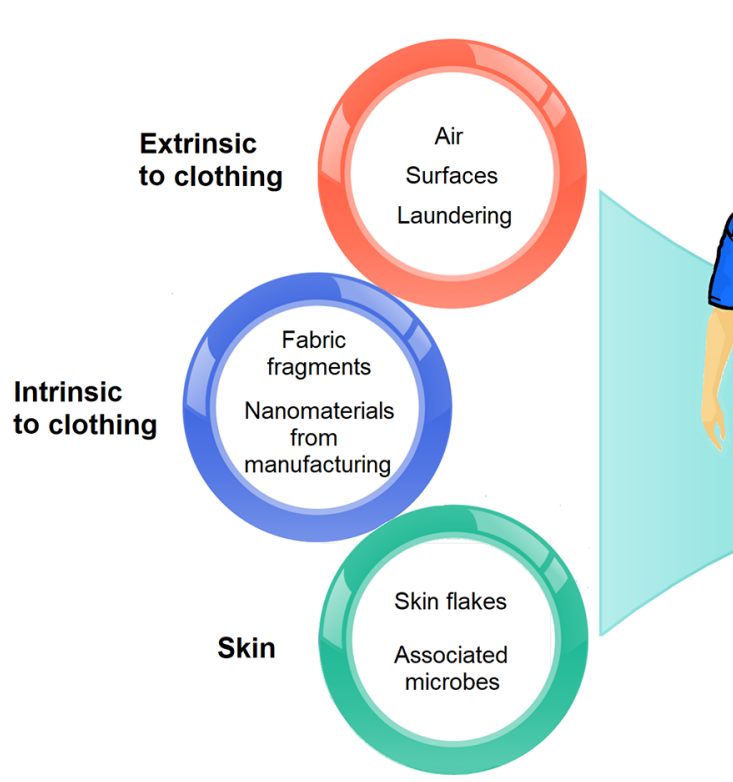

\section{PARTICLE RELEASE}

Figure 4. Particle source categories associated with clothing (left) and mechanisms of size dependent particle release and resuspension characteristics (right). Corresponding references: dominant particle size mode reported by Bhangar et al. ${ }^{199}$ size-resolved emission rates from sitting and walking person reported by Licina et al., ${ }^{202}$ and release of previously deposited particles from clothing (transport vector effect) reported by Licina and Nazaroff. ${ }^{206}$

increments directly from emission rate information. ${ }^{204}$ Additional contributions to exposure from the personal cloud effect can be assessed based on experimental ${ }^{202}$ or numerical ${ }^{143}$ evidence.

It is reasonable to expect that particle exposures associated with clothing occur mainly indoors. As with other indoor particle sources, emission rates can be inferred from measuring time- and size-resolved particle concentrations in chamber experiments with controlled environmental conditions (e.g., known ventilation rate and low particle backgrounds) and simulated activities. ${ }^{199,202}$ It is also plausible to infer emission rates from field observations; however, doing so for clothingassociated particle emissions poses the challenge of separately accounting for resuspension from flooring, commonly an important source of coarse particles indoors. ${ }^{205}$

In assessing clothing-associated emissions, it is worthwhile to differentiate broadly among three particle source categories (see Figure 4). One category is skin flakes, known as squames, generated through frictional interaction between clothing and skin. These squames consist of skin fragments with associated microbes, especially bacteria. A second category would be particles intrinsic to the clothing fabric such as fabric fragments and nanoparticle additives. A third category, the broadest, is exogenous particles that become associated with clothing articles by means of environmental transfer. The first category has been studied most carefully in connection with concerns about hospital-acquired infections. Concern about the second category is increasing, in part due to the emerging use of nanoparticle fabric treatments. The third category would be relevant for concerns as diverse as allergen exposure, paraoccupational exposure, and general enhancements of airborne particles via the personal cloud.

For squame emissions associated with clothing, key factors would include the state of the skin surface (dryness, for example), the nature and intensity of frictional interaction between fabric and skin, and the tightness of the weave.
Variability in the emissions of skin-associated Staphyloccus aureus among individuals has been demonstrated to be large and systematically higher for men than for women. ${ }^{184}$ Notwithstanding a long history of studies, the issue of what should be worn by medical staff in the operating theater to minimize surgical site infections remains a subject of debate. ${ }^{207}$ For intrinsic particle emissions (e.g., nanoparticle additives), one expects that important factors affecting emissions would include initial particle loading of the fabric, the nature of bonding with fibers, the nature and intensity of movement generating frictional forces, and the overall wear of the fabric.

For emissions of exogenous particles, one might envision clothing articles as environmental reservoirs and aim to account for the net movement of particles between these reservoirs and the surroundings. Consider an article of clothing such as a T-shirt passing through a cycle starting with laundering. The washing cycle might effectively remove previously deposited particles but could conceivably add particles from dissolved salts in the wash water and from detergent residue. A tumble-dry cycle could effectively add some airborne exogenous particles filtered by the clothing items from the drying air that passes through the drum. The clothing article might then lose some of these particles and contribute an increment of exposure during the postlaundry handling of folding and placing in storage. When worn, the Tshirt can acquire exogenous particles by deposition from the air and by direct contact with particle-laden surfaces. Exogenous particles may also be acquired during storage intervals, especially if exposed in a manner that would be influenced by settling dust. The accumulation of particles during these processes could be quantified through deposition assessments, for example through the multiplicative combination of exposure concentrations of particles, a suitable deposition velocity, and duration of exposure. Knowing the size-resolved and composition-specific quantities of exogenous particles on a clothing article, one could assess the emission rate through the 
use of loss-rate coefficients. An analogous approach has been used to systematically investigate particle resuspension from walking. ${ }^{205}$

3.3. Factors Affecting Clothing-Mediated Particle Exposures. The previous section outlined an approach that could be used to systematically assess clothing-associated exposures to particles. Specific information about relevant factors and processes is sparse. This section describes what is known from prior experimental investigations about the major factors that influence the size-dependent emissions of particles associated with clothing, emphasizing the relationship to inhalation exposures.

Early studies revealed important findings about clothingskin surface interaction as a means of liberating bacteria-laden skin flakes. ${ }^{178,179,182-184,208-211}$ Recent advances in DNAbased measurements have enabled rapid progress in characterizing the human microbiome, including detailed descriptions of diverse communities of bacteria ${ }^{212,213}$ and fungi ${ }^{214}$ present on human skin. Analyses of clothing surface samples or air exposed to clothing have revealed populations of pathogenic bacteria, ${ }^{164,176}$ respiratory syncytial virus, ${ }^{177}$ fungi, ${ }^{215,216}$ dust mite and cat allergens, endotoxins, ${ }^{157,217}$ and allergenic pollen. ${ }^{158-160}$ Some quantitative evidence exists documenting microbial transfer to clothing from skin ${ }^{210}$ and by hand, ${ }^{218,219}$ although more studies are needed to quantify this phenomenon and better characterize the process mechanistically.

Available evidence suggests that the rate of particle release from clothing fibers is influenced by a combination of three main factors: properties of clothing, environmental conditions, and human factors. A dominant factor influencing release is the intensity of movement. Up to an order of magnitude higher emission rates have been observed during vigorous bodily movement compared to slight activity, presumably owing to increased frictional interactions between clothing fibers and skin. ${ }^{182,199,202,220}$ Men have been found to release significantly more particles compared to women. ${ }^{184,211,221-224}$ Application of skin lotion has been linked to reduced dispersal rate of biotic particles. $^{201,223}$ Some studies, ${ }^{221,225,226}$ but not all, ${ }^{223,227}$ have found that the emission rate of biotic particles from clothingskin interactions increases within an hour after showering. Transport of particles through clothing surfaces and subsequent dispersal can be reduced by wearing tightly woven and nonwoven fabrics. ${ }^{179,224,228}$

A few recent studies have applied a material-balance approach to infer size-resolved biotic particle emission rates associated with human occupancy. Qian et al. ${ }^{229}$ used quantitative PCR to infer that a single university classroom occupant contributes effective emissions of 37 million bacterial genomes per hour with a modal aerodynamic diameter of 3-5 $\mu \mathrm{m}$. However, that study could not differentiate between emissions associated with clothing and those from other sources such as resuspension from a carpeted floor. Bhangar et al. $^{230}$ applied a laser-induced fluorescence technique to quantify the per person emission rate of fluorescent biological aerosol particles (FBAP) in the size range $1-15 \mu$ m diameter in an uncarpeted university classroom. Their work, which again did not isolate the contribution of clothing, yielded an average emission rate of 2 million FBAP per hour with modal diameters of 3-4 $\mu \mathrm{m}$. In a subsequent chamber study, Bhangar et al. ${ }^{199}$ found that at least $60-70 \%$ of occupancy-associated FBAP emissions originated from the floor. However, they also found that "clothing, or its frictional interaction with human skin, was...a source of coarse particles, and especially of the highly fluorescent fraction." That study also revealed a dominant size mode for FBAP of $3-5 \mu \mathrm{m}$ diameter.

When considering the specific issue of infectious disease transmission in relation to clothing, the persistence and survival of infectious agents on fabrics need to be considered. Variation in building environmental conditions and properties of clothing fabrics produces various effects on microbial persistence and survival. ${ }^{231,232}$ Longitudinal assessment of bacteria survival across different studies showed a remarkably high persistence from several days up to more than 90 days for isolates of VRE and MRSA. ${ }^{176,233,234}$ Survival and persistence of viruses and fungi on clothing fabrics has similar days- to months-long time scales. ${ }^{215,235}$ Among different factors influencing survival and persistence, relative humidity and fabric material have been explored. Increased relative humidity (from 35 to $78 \%$ ) has been linked to reduced stability of both bacterial and viral strains in clothing. ${ }^{235,236}$ Survival and persistence of bacteria, viruses, and fungi is higher on commonly used polyester and wool fabrics compared to cotton materials. ${ }^{215,235-237}$

Another common theme in the literature concerning clothing-mediated exposure to pathogenic microbes considers the effectiveness of laundering practices such as washing, drying, and ironing. Mechanical removal includes fabric agitation assisted by surfactant properties of detergents, while inactivation processes can occur as a consequence of elevated water temperature combined with laundry additives such as sodium hypochlorite. Among relevant studies, Callewaert et $\mathrm{al}^{238}$ documented microbial exchanges among clothing articles during washing. Nordstrom et al. ${ }^{239}$ found that home-washed hospital scrubs had increased prevalence of bacterial species compared to those laundered in hospitals, presumably due to low temperature washing. A 7-log reduction in bacterial load can be achieved by $10 \mathrm{~min}$ of washing with $60{ }^{\circ} \mathrm{C}$ water. ${ }^{240}$ Adding sodium hypochlorite to a detergent is an effective way to eliminate bacteria and inactivate enteric and respiratory viruses; $^{241,242}$ however, it might also lead to increases in the abundance of chlorinated organic compounds on clothing. ${ }^{121}$ Detergents free of bleach can reduce the prevalence of Staphyloccus aureus, ${ }^{243}$ while adding bleach-enriched detergents completely eliminates the same. Recent adjustments in laundering procedures include addition of enzymes, reduced water use, lower water temperature, and bleach-free detergents. ${ }^{244-246}$

Both biotic and abiotic material can be deposited onto clothing surfaces from various environmental sources, including outdoor air, ${ }^{158,159,247}$ grassland, ${ }^{160}$ residential air, ${ }^{248}$ public transport microenvironments, ${ }^{249}$ and from physical contact with items such as furniture, storage surfaces, and car seats. ${ }^{250-252}$ The rate of deposition from air to clothing can be described using the deposition velocity concept. ${ }^{253}$ Studies have found that particle size and local air movement are dominant influencing factors. ${ }^{249,254}$

Research has clearly documented that previously deposited material can be released into air from clothing. ${ }^{197,206,255,256}$ For example, using a controlled chamber study approach, Licina and Nazaroff ${ }^{206}$ found that $0.3-3 \%$ of deposited particles (size range $1-10 \mu \mathrm{m}$ ) deposited through settling could be released via fabric motion. In that work, the release fraction monotonically increased with particle size.

The degree of particle binding to clothing fibers and the rate of resuspension may arise from a combined influence of different forces acting upon the fibers. The forces governing 
the release of clothing-embedded particles are abrasive actions between clothing surfaces-a consequence of physical activity of a wearer. ${ }^{182,184}$ Forces influencing release are strongly linked to particle size. Because detachment forces increase more strongly with particle diameter than do adhesion forces, clothing-associated emissions are more discernible among coarse-mode than fine-mode particles. ${ }^{199-202}$

Common clothing fibers are wool, cotton, and polyester. Wool has been reported to have particle release rates up to 10 times higher than the other two materials; ${ }^{149,257}$ cotton exhibits higher emissions than polyester. ${ }^{220}$ The higher particle emissions from wool garments could be linked to different surface roughness and weave pattern ${ }^{258}$ but also to less frequent laundering as compared to cotton and polyester fabrics. ${ }^{257}$ Other clothing conditions found to increase particle release rate include increased clothing age ${ }^{259}$ and reduced cleanliness. $^{149,257}$ While it is generally understood that adhesion forces acting on particles increase with relative humidity, we know of only two studies that have examined its effect on clothing-associated emissions. Yoon and Brimblecombe $^{257}$ found an association between low relative humidity and increased particle emission rate, whereas Zhou et al. ${ }^{201}$ reported an insignificant influence.

\section{FUTURE OUTLOOK}

There is ample evidence that clothing influences human exposure to chemicals and particles. Yet, only a few studies have quantified clothing-mediated exposure by means of direct measurements. ${ }^{7,11,15,24-26,28-30,149,202}$

We know surprisingly little about the occurrence of contaminants acquired by everyday clothing after purchase. For a relatively low cost, we could learn a large amount from simply assessing the occurrence, concentrations, and extractability (e.g., by sweat and saliva) of chemicals and particles in everyday clothing. Cross-sectional exposure studies would greatly benefit from the addition of clothing analyses, potentially identifying direct connections between clothingassociated exposure and health.

The diversity of clothing, environmental, and human factors make predicting exposures challenging. Therefore, it will be important to reduce the many variables to those that are most influential. Progress can be achieved through models and laboratory and field investigations of human exposure and uptake. In addition to chemical properties, important factors affecting exposures may include textile materials, weave, thickness, and permeability; wear, care, and storage practices; environmental conditions; intensity and types of activities; skin-oil transfer to clothing and its aging; human physiology (skin integrity, lipid generation, sweating); and personal hygiene habits. Simulated exposures with human subjects also should consider pollutant transfer from textiles other than clothing (e.g., pillows, quilts, bed linen). The sleeping environment is potentially of great importance in this matter given the large proportion of time spent in bed.

Predicting and controlling exposure rely on adequate understanding of underlying mechanisms. A robust literature describes transport mechanisms for chemicals among environmental reservoirs. Reasonable approaches have been proposed for assessing risk and exposure to chemicals in clothing. However, we have limited in vivo evaluations of such assessments. Compared with chemical transport, mechanisms of particle uptake and subsequent release from clothing are even less well understood. Further quantitative investigations of factors that drive acquisition, retention, and transmission of biotic and abiotic particles in clothing are needed to better link such processes to clothing associated exposures. We also need to better understand the extent to which clothing plays a role in the spread of infectious disease. Considerable research has focused on textile innovations and personal protective clothing designed to limit the spread of infectious agents in hospital environments. Researchers could usefully build upon lessons learned and consider the potential utility of incorporating such innovations in everyday clothing.

One should anticipate that future changes in clothing will influence exposure. The useful lifetime of some clothing has become shorter. High turnover (short ownership time) might yield greater exposure to chemicals that are present in newly purchased clothing with proportionately less exposure to environmental chemicals that require a long period to equilibrate (e.g., high molecular weight phthalates). Similarly, increased use of antimicrobial agents as coatings on clothing articles may increase uptake of nanoparticles by the human body and lead to altered toxicological effects. Worth noting is that people in Western countries commonly have closets full of clothes that are rarely worn. These articles may have sufficient time to equilibrate with the chemicals present in their storage environment. Worldwide, demand for synthetic fabrics is increasing. ${ }^{260}$ Synthetics have chemical partitioning behaviors and moisture holding capacities that differ from those of natural fibers, altering the capacity to be reservoirs of contaminants. Advances in materials and adjustments in laundering procedures may also influence how clothing is cared for and how chemicals and particles are acquired and retained in clothing. Increased recycling and reuse of clothing can influence tertiary exposures.

People spend nearly their entire lives in intimate contact with clothing and other textiles. The evidence reviewed in this article supports a view that this environmental compartment plays important roles in exposure and health risk. Consequently, clothing as a mediator of chemical and particle exposure deserves substantial attention from the environmental science research and regulatory communities.

\section{AUTHOR INFORMATION}

\section{Corresponding Author}

*Phone: +1 919966 5452; e-mail: glennmor@email.unc.edu. ORCID

Glenn C. Morrison: 0000-0001-6876-7185

Charles J. Weschler: 0000-0002-9097-5850

\section{Notes}

The authors declare no competing financial interest.

\section{REFERENCES}

(1) Zartarian, V. G.; Ott, W. R.; Duan, N. Basic concepts and definitions of exposure and dose. In Exposure Analysis; Ott, W. R., Steinemann, A. C., Wallace, L. A., Eds.;CRC Press: Boca Raton, 2007; pp 33-63.

(2) BfR. Introduction to the Problems Surrounding Garment Textiles. Updated BfR Opinion No. 041/2012; Bundesinstitut für Risikobewertung, 2012. Available at: http://www.bfr.bund.de/cm/ 349/introduction-to-the-problems-surrounding-garment-textiles.pdf (accessed January 4, 2019).

(3) KEMI. Chemicals in textile-Risks to human health and the environment. Report from a government assignment, REPORT 6/14; Swedish Chemicals Agency, 2014. Available at: https://www.kemi.se/ 
files/8040fb7a4f2547b7bad522c399c0b649/report6-14-chemicals-intextiles.pdf (accessed January 4, 2019).

(4) Rovira, J.; Domingo, J. L. Human health risks due to exposure to inorganic and organic chemicals from textiles: A review. Environ. Res. 2019, 168, 62-69.

(5) Wijnhoven, S. W. P.; Kooi, M. W.; Te Biesebeek, J. D. Consumer exposure to chemicals in indoor environment: A specific focus on chemicals from textile products. Letter report 320104010; National Institute for Public Health and the Enviroment: Bilthoven, the Netherlands, 2010. Available at: https://www.rivm.nl/bibliotheek/ rapporten/320104010.html (accessed January 4, 2019).

(6) Mitchell, A.; Spencer, M.; Edmiston, C., Jr. Role of healthcare apparel and other healthcare textiles in the transmission of pathogens: a review of the literature. Journal of Hospital Infection. 2015, 90, 285292.

(7) Blum, A.; Gold, M. D.; Ames, B. N.; Jones, F. R.; Hett, E. A.; Dougherty, R. C.; Horning, E. C.; Dzidic, I.; Carroll, D. I.; Stillwell, R. N.; Thenot, J.-P. Children absorb Tris-BP flame retardant from sleepwear: Urine contains the mutagenic metabolite, 2,3-dibromopropanol. Science 1978, 201, 1020-1023.

(8) Ulsamer, A. G.; Porter, W. K.; Osterberg, R. E. Percutaneous absorption of radiolabeled TRIS from flame-retarded fabric. Journal of Environmental Pathology and Toxicology 1978, 1, 543-549.

(9) Armstrong, R. W.; Eichner, E. R.; Klein, D. E.; Barthel, W. F.; Bennett, J. V.; Jonsson, V.; Bruce, H.; Loveless, L. E. Pentachlorophenol poisoning in a nursery for newborn infants. II. Epidemiologic and toxicologic studies. J. Pediatr. 1969, 75, 317-325.

(10) Brown, B. W. Fatal phenol poisoning from improperly laundered diapers. American Journal of Public Health. 1970, 60, 901-902.

(11) Rossbach, B.; Kegel, P.; Süß, H.; Letzel, S. Biomonitoring and evaluation of permethrin uptake in forestry workers using permethrintreated tick-proof pants. J. Exposure Sci. Environ. Epidemiol. 2016, 26, 95-103.

(12) Wester, R. C.; Quan, D.; Maibach, H. I. In vitro percutaneous absorption of model compounds glyphosate and malathion from cotton fabric into and through human skin. Food Chem. Toxicol. 1996, 34, 731-735.

(13) Wester, R. C.; Hartway, T.; Serranzana, S.; Maibach, H. I. Human skin in vitro percutaneous absorption of gaseous ethylene oxide from fabric. Food Chem. Toxicol. 1997, 35, 513-515.

(14) Iadaresta, F.; Manniello, M. D.; Östman, C.; Crescenzi, C.; Holmbäck, J.; Russo, P. Chemicals from textiles to skin: an in vitro permeation study of benzothiazole. Environ. Sci. Pollut. Res. 2018, 25, 24629-24638.

(15) Horstmann, M.; McLachlan, M. S. Textiles as a source of polychlorinated dibenzo-p-dioxins and dibenzofurans (PCDD/F) in human skin and sewage sludge. Environ. Sci. Pollut. Res. 1994, 1, 1520.

(16) Klasmeier, J.; Mühlebach, A.; McLachlan, M. S. PCDD/Fs in textiles - Part II: Transfer from clothing to human skin. Chemosphere 1999, 38, 97-108.

(17) Meinke, M.; Abdollahnia, M.; Gähr, F.; Platzek, T.; Sterry, W.; Lademann, J. Migration and penetration of a fluorescent textile dye into the skin - in vivo versus in vitro methods. Exp. Dermatol. 2009, 18, 789-792.

(18) Knishkowy, B.; Baker, E. L. Transmission of occupational disease to family contacts. Am. J. Ind. Med. 1986, 9, 543-550.

(19) Fischbein, A.; Wolff, M. S. Conjugal exposure to polychlorinated biphenyls (PCBs). Br. J. Ind. Med. 1987, 44, 284-286.

(20) Raymer, J. H.; Studabaker, W. B.; Gardner, M.; Talton, J.; Quandt, S. A.; Chen, H.; Michael, L. C.; McCombs, M.; Arcury, T. A. Pesticide exposures to migrant farmworkers in eastern NC: Detection of metabolites in farmworker urine associated with housing violations and camp characteristics. Am. J. Ind. Med. 2014, 57, 323-337.

(21) Deziel, N. C.; Friesen, M. C.; Hoppin, J. A.; Hines, C. J.; Thomas, K.; Beane Freeman, L. E. A review of nonoccupational pathways for pesticide exposure in women living in agricultural areas. Environ. Health Perspect. 2015, 123, 515-524.
(22) Bradman, A.; Schwartz, J. M.; Fenster, L.; Barr, D. B.; Holland, N. T.; Eskenazi, B. Factors predicting organochlorine pesticide levels in pregnant Latina women living in a United States agricultural area. J. Exposure Sci. Environ. Epidemiol. 2007, 17, 388-399.

(23) Park, J.-S.; Voss, R. W.; McNeel, S.; Wu, N.; Guo, T.; Wang, Y.; Israel, L.; Das, R.; Petreas, M. High exposure of California firefighters to polybrominated diphenyl ethers. Environ. Sci. Technol. 2015, 49, 2948-2958.

(24) Piotrowski, J. Further investigations on the evaluation of exposure to nitrobenzene. Br. J. Ind. Med. 1967, 24, 60-65.

(25) Piotrowski, J. K. Evaluation of exposure to phenol: absorption of phenol vapour in the lungs and through the skin and excretion of phenol in urine. Br. J. Ind. Med. 1971, 28, 172-178.

(26) Morrison, G. C.; Weschler, C. J.; Bekö, G.; Koch, H. M.; Salthammer, T.; Schripp, T.; Toftum, J.; Clausen, G. Role of clothing in both accelerating and impeding dermal absorption of airborne SVOCs. J. Exposure Sci. Environ. Epidemiol. 2016, 26, 113-118.

(27) Weschler, C. J.; Bekö, G.; Koch, H. M.; Salthammer, T.; Schripp, T.; Toftum, J.; Clausen, G. Transdermal uptake of diethyl phthalate and di(n-butyl) phthalate directly from air: Experimental verification. Environ. Health Perspect. 2015, 123, 928-934.

(28) Bekö, G.; Morrison, G.; Weschler, C. J.; Koch, H. M.; Pälmke, C.; Salthammer, T.; Schripp, T.; Toftum, J.; Clausen, G. Measurements of dermal uptake of nicotine directly from air and clothing. Indoor Air. 2017, 27, 427-433.

(29) Bekö, G.; Morrison, G.; Weschler, C. J.; Koch, H. M.; Pälmke, C.; Salthammer, T.; Schripp, T.; Eftekhari, A.; Toftum, J.; Clausen, G. Dermal uptake of nicotine from air and clothing: Experimental verification. Indoor Air. 2018, 28, 247-257.

(30) Morrison, G. C.; Bekö, G.; Weschler, C. J.; Schripp, T.; Salthammer, T.; Hill, J.; Andersson, A.-M.; Toftum, J.; Clausen, G.; Frederiksen, H. Dermal uptake of benzophenone-3 from clothing. Environ. Sci. Technol. 2017, 51, 11371-11379.

(31) Gong, M.; Weschler, C. J.; Zhang, Y. Impact of clothing on dermal exposure to phthalates: Observations and insights from sampling both skin and clothing. Environ. Sci. Technol. 2016, 50, $4350-4357$.

(32) Liu, X.; Yu, G.; Cao, Z.; Wang, B.; Huang, J.; Deng, S.; Wang, Y.; Shen, H.; Peng, X. Estimation of human exposure to halogenated flame retardants through dermal adsorption by skin wipe. Chemosphere 2017, 168, 272-278.

(33) Moore, C. A.; Wilkinson, S. C.; Blain, P. G.; Dunn, M.; Aust, G. A.; Williams, F. M. Use of a human skin in vitro model to investigate the influence of 'every-day' clothing and skin surface decontamination on the percutaneous penetration of organophosphates. Toxicol. Lett. 2014, 229, 257-264.

(34) Gaskin, S.; Heath, L.; Pisaniello, D.; Edwards, J. W.; Logan, M.; Baxter, C. Dermal absorption of fumigant gases during HAZMAT incident exposure scenarios-Methyl bromide, sulfuryl fluoride, and chloropicrin. Toxicol. Ind. Health 2017, 33, 547-554.

(35) Heath, L.; Gaskin, S.; Pisaniello, D.; Crea, J.; Logan, M.; Baxter, C. Skin absorption of ethylene oxide gas following exposures relevant to HAZMAT incidents. Annals of Work Exposures and Health. 2017, $61,589-595$.

(36) Hatch, K. L.; Maibach, H. I. Textile chemical finish dermatitis. Contact Dermatitis 1986, 14, 1-13.

(37) Hatch, K. L.; Maibach, H. I. Textile dye dermatitis. J. Am. Acad. Dermatol. 1995, 32, 631-639.

(38) Hatch, K. L.; Maibach, H. I. Textile dye allergic contact dermatitis prevalence. Contact Dermatitis 2000, 42, 187-195.

(39) Malinauskiene, L.; Bruze, M.; Ryberg, K.; Zimerson, E.; Isaksson, M. Contact allergy from disperse dyes in textiles - a review. Contact Dermatitis 2013, 68, 65-75.

(40) De Groot, A. C.; Le Coz, C. J.; Lensen, G. J.; Flyvholm, M.-A.; Maibach, H. I.; Coenraads, P.-J. Formaldehyde-releasers: relationship to formaldehyde contact allergy. Formaldehyde-releasers in clothes: durable press chemical finishes. Part 1. Contact Dermatitis 2010, 62, 259-271. 
(41) De Groot, A. C.; Le Coz, C. J.; Lensen, G. J.; Flyvholm, M.-A.; Maibach, H. I.; Coenraads, P.-J. Formaldehyde-releasers: relationship to formaldehyde contact allergy. Part 2. Formaldehyde-releasers in clothes: durable press chemical finishes. Contact Dermatitis 2010, 63, $1-9$.

(42) Tsuboy, M. S.; Angeli, J. P. F.; Mantovani, M. S.; Knasmüller, S.; Umbuzeiro, G. A.; Ribeiro, L. R. Genotoxic, mutagenic and cytotoxic effects of the commercial dye CI Disperse Blue 291 in the human hepatic cell line HepG2. Toxicol. In Vitro 2007, 21, 16501655.

(43) Leme, D. M.; De Oliveira, G. A. R.; Meireles, G.; Dos Santos, T. C.; Zanoni, M. V. B.; De Oliveira, D. P. Genotoxicological assessment of two reactive dyes extracted from cotton fibres using artificial sweat. Toxicol. In Vitro 2014, 28, 31-38.

(44) Güngördü, A.; Birhanli, A.; Ozmen, M. Biochemical response to exposure to six textile dyes in early developmental stages of Xenopus laevis. Environ. Sci. Pollut. Res. 2013, 20, 452-460.

(45) Birhanli, A.; Ozmen, M. Evaluation of the toxicity and teratogenity of six commercial textile dyes using the frog embryo teratogenesis assay - Xenopus. Drug Chem. Toxicol. 2005, 28, 51-65. (46) Kramer, A.; Guggenbichler, P.; Heldt, P.; Jünger, M.; Ladwig, A.; Thierbach, H.; Weber, U.; Daeschlein, G. Hygienic relevance and risk assessment of antimicrobial-impregnated textiles. Current Problems in Dermatology. 2006, 33, 78-109.

(47) Dann, A. B.; Hontela, A. Triclosan: environmental exposure, toxicity and mechanisms of action. J. Appl. Toxicol. 2011, 31, 285311.

(48) Kim, Y. R.; Harden, F. A.; Toms, L.-M. L.; Norman, R. E. Health consequences of exposure to brominated flame retardants: A systematic review. Chemosphere 2014, 106, 1-19.

(49) Jurewicz, J.; Hanke, W. Exposure to phthalates: Reproductive outcome and children health. A review of epidemiological studies. International Journal of Occupational Medicine and Environmental Health. 2011, 24, 115-141.

(50) Braun, J. M.; Sathyanarayana, S.; Hauser, R. Phthalate exposure and children's health. Curr. Opin. Pediatr. 2013, 25, 247-254.

(51) Viberg, H.; Lee, I.; Eriksson, P. Adult dose-dependent behavioral and cognitive disturbances after a single neonatal PFHxS dose. Toxicology 2013, 304, 185-191.

(52) Wolf, C. J.; Fenton, S. E.; Schmid, J. E.; Calafat, A. M.; Kuklenyik, Z.; Bryant, X. A.; Thibodeaux, J.; Das, K. P.; White, S. S.; Lau, C. S.; Abbott, B. D. Developmental toxicity of perfluorooctanoic acid in the CD-1 mouse after cross-foster and restricted gestational exposures. Toxicol. Sci. 2007, 95, 462-473.

(53) Bomgardner, M. Greener textile dyeing. Chemical and Engineering News 2018, 96 (29), 28-33.

(54) Abel-Ghany, H. A. Study of radon, thoron and toxic elements in some textile dyes. J. Radioanal. Nucl. Chem. 2013, 295, 1365-1370.

(55) Nguyen, T.; Saleh, M. A. Exposure of women to trace elements through the skin by direct contact with underwear clothing. J. Environ. Sci. Health, Part A: Toxic/Hazard. Subst. Environ. Eng. 2017, 52, 1-6.

(56) Rovira, J.; Nadal, M.; Schuhmacher, M.; Domingo, J. L. Human exposure to trace elements through the skin by direct contact with clothing: Risk assessment. Environ. Res. 2015, 140, 308-316.

(57) Rovira, J.; Nadal, M.; Schuhmacher, M.; Domingo, J. L. Trace elements in skin-contact clothes and migration to artificial sweat: Risk assessment of human dermal exposure. Text. Res. J. 2017, 87, 726738.

(58) Rovira, J.; Nadal, M.; Schuhmacher, M.; Domingo, J. L. Home textile as a potential pathway for dermal exposure to trace elements: assessment of health risks. J. Text. Inst. 2017, 108, 1966-1974.

(59) Rybicki, E.; Święch, T.; Leśniewska, E.; Albińska, J.; Szynkowska, M. I.; Paryjczak, T.; Sypniewski, S. Changes in hazardous substances in cotton after mechanical and chemical treatments of textiles. Fibres \& Textiles in Eastern Europe 2004, 12, 67-73.

(60) Sungur, S..; Gülmez, F. Determination of metal contents of various fibers used in textile industry by MP-AES. J. Spectrosc. 2015, $2015,640271$.
(61) Szynkowska, M. I.; Rybicki, E.; Leśniewska, E.; Pawlaczyk, A.; Paryjczak, T.; Matyjas-Zgondek, E. Influence of production progress on the heavy metal content in flax fibers. Chemical Papers 2009, 63, $537-542$.

(62) Tuzen, M.; Onal, A.; Soylak, M. Determination of trace heavy metals in some textile products produced in Turkey. Bull. Chem. Soc. Ethiop. 2008, 22, 379-384.

(63) Freeman, H. S. Aromatic amines: use in azo dye chemistry. Front. Biosci., Landmark Ed. 2013, 18, 145-164.

(64) Kawakami, T.; Isama, K.; Nakashima, H.; Tsuchiya, T.; Matsuoka, A. Analysis of primary aromatic amines originated from azo dyes in commercial textile products in Japan. J. Environ. Sci. Health, Part A: Toxic/Hazard. Subst. Environ. Eng. 2010, 45, 1281-1295.

(65) Antal, B.; Kuki, Á.; Nagy, L.; Nagy, T.; Zsuga, M.; Kéki, S. Rapid detection of hazardous chemicals in textiles by direct analysis in real-time mass spectrometry (DART-MS). Anal. Bioanal. Chem. 2016, 408, 5189-5198.

(66) Lam, P.-L.; Kan, C.-W.; Yuen, M. C.-W.; Cheung, S.-Y.; Gambari, R.; Lam, K.-H.; Tang, J. C.-O.; Chui, C.-H. Studies on quinoline type dyes and their characterisation studies on acrylic fabric. Color. Technol. 2012, 128, 192-198.

(67) Luongo, G.; Thorsén, G.; Östman, C. Quinolines in clothing textiles - a source of human exposure and wastewater pollution? Anal. Bioanal. Chem. 2014, 406, 2747-2756.

(68) Luongo, G.; Avagyan, R.; Hongyu, R.; Östman, C. The washout effect during laundry on benzothiazole, benzotriazole, quinoline, and their derivatives in clothing textiles. Environ. Sci. Pollut. Res. 2016, 23, 2537-2548.

(69) Luongo, G.; Iadaresta, F.; Moccia, E.; Östman, C.; Crescenzi, C. Determination of aniline and quinoline compounds in textiles. Journal of Chromatography A 2016, 1471, 11-18.

(70) Xue, J.; Liu, W.; Kannan, K. Bisphenols, benzophenones, and bisphenol A diglycidyl ethers in textiles and infant clothing. Environ. Sci. Technol. 2017, 51, 5279-5286.

(71) Zhang, S.-X.; Chai, X.-S.; Huang, B.-X.; Mai, X.-X. A robust method for determining water-extractable alkylphenol polyethoxylates in textile products by reaction-based headspace gas chromatography. Journal of Chromatography A 2015, 1406, 94-98.

(72) Avagyan, R.; Sadiktsis, I.; Thorsén, G.; Östman, C.; Westerholm, R. Determination of benzothiazole and benzotriazole derivates in tire and clothing textile samples by high performance liquid chromatography-electrospray ionization tandem mass spectrometry. Journal of Chromatography A 2013, 1307, 119-125.

(73) Avagyan, R.; Luongo, G.; Thorsén, G.; Östman, C. Benzothiazole, benzotriazole, and their derivates in clothing textiles-a potential source of environmental pollutants and human exposure. Environ. Sci. Pollut. Res. 2015, 22, 5842-5849.

(74) Liu, W.; Xue, J.; Kannan, K. Occurrence of and exposure to benzothiazoles and benzotriazoles from textiles and infant clothing. Sci. Total Environ. 2017, 592, 91-96.

(75) Guo, J.; Capozzi, S. L.; Kraeutler, T. M.; Rodenburg, L. A. Global distribution and local impacts of inadvertently generated polychlorinated biphenyls in pigments. Environ. Sci. Technol. 2014, 48, $8573-8580$.

(76) Zhu, F.; Ruan, W.; He, M.; Zeng, F.; Luan, T.; Tong, Y.; Lu, T.; Ouyang, G. Application of solid-phase microextraction for the determination of organophosphorus pesticides in textiles by gas chromatography with mass spectrometry. Anal. Chim. Acta 2009, 650, 202-206.

(77) Wu, C.-C.; Bao, L.-J.; Tao, S.; Zeng, E. Y. Dermal uptake from airborne organics as an important route of human exposure to e-waste combustion fumes. Environ. Sci. Technol. 2016, 50, 6599-6605.

(78) Liu, X.; Guo, Z.; Krebs, K. A.; Pope, R. H.; Roache, N. F. Concentrations and trends of perfluorinated chemicals in potential indoor sources from 2007 through 2011 in the US. Chemosphere 2014, 98, 51-57.

(79) Liu, X.; Guo, Z.; Folk IV, E. E.; Roache, N. F. Determination of fluorotelomer alcohols in selected consumer products and preliminary 
investigation of their fate in the indoor environment. Chemosphere 2015, 129, 81-86.

(80) Lv, G.; Wang, L.; Liu, S.; Li, S. Determination of perfluorinated compounds in packaging materials and textiles using pressurized liquid extraction with gas chromatography-mass spectrometry. Anal. Sci. 2009, 25, 425-429.

(81) Renner, R. Growing concern over perfluorinated chemicals. Environ. Sci. Technol. 2001, 35, 154A-160A.

(82) Schettler, T. Human exposure to phthalates via consumer products. Int. J. Androl. 2006, 29, 134-139.

(83) Tønning, K.; Malmgren-Hansen, B.; Jacobsen, E.; Pedersen, E.; Nilsson, N. H. Survey of Chemical Substances in Consumer Products, No. 107 2010. Phthalates in Plastic Sandals; Danish Ministry of the Environment, Environmental Protection Agency: 2010.

(84) Laursen, S. E.; Hansen, J.; Drøjdahl, A.; Hansen, O. C.; Pommer, K.; Pedersen, E.; Bernth, N. Survey of Chemicals in Consumer Products, Nr. 23. Survey of Chemical Compounds in Textile Fabrics Danish Environmental Protection Agency: Copenhagen; 2003.

(85) Fowler, J. F.; Skinner, S. M.; Belsito, D. V. Allergic contact dermatitis from formaldehyde resins in permanent press clothing: An underdiagnosed cause of generalized dermatitis. J. Am. Acad. Dermatol. 1992, 27, 962-968.

(86) De Groot, A. C.; Maibach, H. I. Does allergic contact dermatitis from formaldehyde in clothes treated with durable-press chemical finishes exist in the USA? Contact Dermatitis 2010, 62, 127-136.

(87) Lentini, J. J.; Dolan, J. A.; Cherry, C. The petroleum-laced background. J. Forensic Sci. 2000, 45, 968-989.

(88) Lao, J.-Y.; Xie, S.-Y.; Wu, C.-C.; Bao, L.-J.; Tao, S.; Zeng, E. Y. Importance of dermal absorption of polycyclic aromatic hydrocarbons derived from barbecue fumes. Environ. Sci. Technol. 2018, 52, 83308338.

(89) Morrison, G.; Li, H.; Mishra, S.; Buechlein, M. Airborne phthalate partitioning to cotton clothing. Atmos. Environ. 2015, 115, $149-152$.

(90) Morrison, G.; Shakila, N. V.; Parker, K. Accumulation of gasphase methamphetamine on clothing, toy fabrics, and skin oil. Indoor Air. 2015, 25, 405-414.

(91) Morrison, G. C.; Andersen, H. V.; Gunnarsen, L.; Varol, D.; Uhde, E.; Kolarik, B. Partitioning of PCBs from air to clothing materials in a Danish apartment. Indoor Air. 2018, 28, 188-197.

(92) Saini, A.; Thaysen, C.; Jantunen, L.; McQueen, R. H.; Diamond, M. L. From clothing to laundry water: investigating the fate of phthalates, brominated flame retardants, and organophosphate esters. Environ. Sci. Technol. 2016, 50, 9289-9297.

(93) Saini, A.; Rauert, C.; Simpson, M. J.; Harrad, S.; Diamond, M. L. Characterizing the sorption of polybrominated diphenyl ethers (PBDEs) to cotton and polyester fabrics under controlled conditions. Sci. Total Environ. 2016, 563-564, 99-107.

(94) Saini, A.; Okeme, J. O.; Parnis, J. M.; McQueen, R. H.; Diamond, M. L. From air to clothing: Characterizing the accumulation of semi-volatile organic compounds to fabrics in indoor environments. Indoor Air 2017, 27, 631-641.

(95) Weschler, C. J.; Nazaroff, W. W. Semivolatile organic compounds in indoor environments. Atmos. Environ. 2008, 42, 9018-9040.

(96) Piadé, J. J.; D’Andrés, S.; Sanders, E. B. Sorption phenomena of nicotine and ethenylpyridine vapors on different materials in a test chamber. Environ. Sci. Technol. 1999, 33, 2046-2052.

(97) Hung, H.-W.; Lin, T.-F.; Chiou, C. T. Partition coefficients of organic contaminants with carbohydrates. Environ. Sci. Technol. 2010, $44,5430-5436$.

(98) De Coensel, N.; Desmet, K.; Sandra, P.; Górecki, T. Domestic sampling: Exposure assessment to moth repellent products using ultrasonic extraction and capillary GC-MS. Chemosphere 2008, 71, $711-716$.

(99) Wang, Y.; Zeng, Z.; Liu, M. Analysis of naphthalene residues in textile samples by GC-FID using sol-gel-derived SPME fiber. $J$. Chromatogr. Sci. 2011, 49, 29-34.
(100) Gherghel, S.; Morgan, R. M.; Blackman, C. S.; Karu, K.; Parkin, I. P. Analysis of transferred fragrance and its forensic implications. Sci. Justice 2016, 56, 413-420.

(101) Kasting, G. B.; Miller, M. A.; Nitsche, J. M. Absorption and evaporation of volatile compounds applied to skin. In Dermatologic, Cosmeceutic and Cosmetic Development; Walters, K. A., Roberts, M. S., Eds.; Informa Healthcare USA: New York, pp 385-400, 2008.

(102) Guo, Z.; Tichenor, B. A.; Mason, M. A.; Plunket, C. M. The temperature dependence of the emission of perchloroethylene from dry cleaned fabrics. Environ. Res. 1990, 52, 107-115.

(103) Tichenor, B. A.; Sparks, L. E.; Jackson, M. D.; Guo, Z.; Mason, M. A.; Plunkett, C. M.; Rasor, S. A. Emissions of perchloroethylene from dry cleaned fabrics. Atmos. Environ., Part A 1990, 24A, 12191229.

(104) Brigden, K.; Labunska, I.; House, E.; Santillo, D.; Johnston, P. Hazardous Chemicals in Branded Textile Products on Sale in 27 Countries during 2012. Greenpeace Research Laboratories Technical Report 06-2012. Available at: https://archivo-es.greenpeace.org/ espana/Global/espana/report/contaminacion/151012 Technical\%20Note_Product\%20Testing\%20Report_ \%20With\%20Exec\%20summary.pdf (accessed January 4, 2019).

(105) Faulde, M. K.; Uedelhoven, W. M.; Malerius, M.; Robbins, R. G. Factory-based permethrin impregnation of uniforms: Residual activity against Aedes aegypti and Ixodes ricinus in battle dress uniforms worn under field conditions, and cross-contamination during the laundering and storage process. Mil. Med. 2006, 171, 472-477.

(106) Brüschweiler, B. J.; Küng, S.; Bürgi, D.; Muralt, L.; Nyfeler, E. Identification of non-regulated aromatic amines of toxicological concern which can be cleaved from azo dyes used in clothing textiles. Regul. Toxicol. Pharmacol. 2014, 69, 263-272.

(107) Brüschweiler, B. J.; Merlot, C. Azo dyes in clothing textiles can be cleaved into a series of mutagenic aromatic amines which are not regulated yet. Regul. Toxicol. Pharmacol. 2017, 88, 214-226.

(108) Cervantes, F. J.; Dos Santos, A. B. Reduction of azo dyes by anaerobic bacteria: microbiological and biochemical aspects. Rev. Environ. Sci. Bio/Technol. 2011, 10, 125-137.

(109) Platzek, T.; Lang, C.; Grohmann, G.; Gi, U.-S.; Baltes, W. Formation of a carcinogenic aromatic amine from an azo dye by human skin bacteria in vitro. Hum. Exp. Toxicol. 1999, 18, 552-559.

(110) Platzek, T. Risk from exposure to arylamines from consumer products and hair dyes. Front. Biosci., Elite Ed. 2010, 2, 1169-1183.

(111) Stingley, R. L.; Zou, W.; Heinze, T. M.; Chen, H.; Cerniglia, C. E. Metabolism of azo dyes by human skin microbiota. J. Med. Microbiol. 2010, 59, 108-114.

(112) Spadaro, J. T.; Isabelle, L.; Renganathan, V. Hydroxyl radical mediated degradation of azo dyes: evidence for benzene generation. Environ. Sci. Technol. 1994, 28, 1389-1393.

(113) Kajiwara, N.; Desborough, J.; Harrad, S.; Takigami, H. Photolysis of brominated flame retardants in textiles exposed to natural sunlight. Environmental Science: Processes \& Impacts. 2013, 15, 653-660.

(114) Callewaert, C.; De Maeseneire, E.; Kerckhof, F.-M.; Verliefde, A.; Van de Wiele, T.; Boon, N. Microbial odor profile of polyester and cotton clothes after a fitness session. Appl. Environ. Microbiol. 2014, $80,6611-6619$.

(115) McQueen, R. H.; Laing, R. M.; Brooks, H. J. L.; Niven, B. E. Odor intensity in apparel fabrics and the link with bacterial populations. Text. Res. J. 2007, 77, 449-456.

(116) Nicolaides, N. Skin lipids: their biochemical uniqueness. Science 1974, 186, 19-26.

(117) Wisthaler, A.; Tamás, G.; Wyon, D. P.; Strøm-Tejsen, P.; Space, D.; Beauchamp, J.; Hansel, A.; Märk, T. D.; Weschler, C. J. Products of ozone-initiated chemistry in a simulated aircraft environment. Environ. Sci. Technol. 2005, 39, 4823-4832.

(118) Coleman, B. K.; Destaillats, H.; Hodgson, A. T.; Nazaroff, W. W. Ozone consumption and volatile byproduct formation from surface reactions with aircraft cabin materials and clothing fabrics. Atmos. Environ. 2008, 42, 642-654. 
(119) Rai, A. C.; Guo, B.; Lin, C.-H.; Zhang, J.; Pei, J.; Chen, Q. Ozone reaction with clothing and its initiated VOC emissions in an environmental chamber. Indoor Air. 2014, 24, 49-58.

(120) Wisthaler, A.; Weschler, C. J. Reactions of ozone with human skin lipids: Sources of carbonyls, dicarbonyls, and hydroxycarbonyls in indoor air. Proc. Natl. Acad. Sci. U. S. A. 2010, 107, 6568-6575.

(121) Schwartz-Narbonne, H.; Wang, C.; Zhou, S.; Abbatt, J. P. D.; Faust, J. Heterogeneous chlorination of squalene and oleic acid. Environ. Sci. Technol. 2019, 53, 1217-1224.

(122) US EPA. Exposure Factors Handbook, 2011 ed.; EPA/600/R090/052F; US Environmental Protection Agency: Washington DC, 2011

(123) WHO. Dermal Exposure. Environmental Health Criteria 242; World Health Organization, International Program on Chemical Safety: Geneva, Switzerland, 2014.

(124) ECHA. Guidance on information requirements and chemical safety assessment. Chapter R.15: Consumer Exposure Assessment. Report reference ECHA-16-G-07-EN. Version 3; European Chemicals Agency, 2016.

(125) US EPA. Stochastic Human Exposure and Dose Simulation (SHEDS) to Estimate Human Exposure to Chemicals. US Environmental Protection Agency, 2012. Available at: https://www.epa.gov/ chemical-research/stochastic-human-exposure-and-dose-simulationsheds-estimate-human-exposure (accessed April 5, 2019).

(126) Ross, J.; Thongsinthusak, T.; Fong, H. R.; Margetich, S.; Krieger, R. Measuring potential dermal transfer of surface pesticide residue generated from indoor fogger use: An interim report. Chemosphere 1990, 20, 349-360.

(127) Cohen-Hubal, E. A.; Suggs, J. C.; Nishioka, M. G.; Ivancic, W. A. Characterizing residue transfer efficiencies using a fluorescent imaging technique. J. Exposure Sci. Environ. Epidemiol. 2005, 15, 261270.

(128) Appel, K. E.; Gundert-Remy, U.; Fischer, H.; Faulde, M.; Mross, K. G.; Letzel, S.; Rossbach, B. Risk assessment of Bundeswehr (German Federal Armed Forces) permethrin-impregnated battle dress uniforms (BDU). Int. J. Hyg. Environ. Health 2008, 211, 88-104.

(129) Delmaar, J. E.; Bokkers, B. G. H.; Ter Burg, W.; Van Engelen, J. G. M. First tier modeling of consumer dermal exposure to substances in consumer articles under REACH: A quantitative evaluation of the ECETOC TRA for consumers tool. Regul. Toxicol. Pharmacol. 2013, 65, 79-86.

(130) Clausen, P. A.; Spaan, S.; Brouwer, D. H.; Marquart, H.; Le Feber, M.; Engel, R.; Geerts, L.; Jensen, K. A.; Kofoed-Sørensen, V.; Hansen, B.; De Brouwere, K. Experimental estimation of migration and transfer of organic substances from consumer articles to cotton wipes: Evaluation of underlying mechanisms. J. Exposure Sci. Environ. Epidemiol. 2016, 26, 104-112.

(131) Saleh, M. A.; Kamel, A.; El-Demerdash, A.; Jones, J. Penetration of household insecticides through different types of textile fabrics. Chemosphere 1998, 36, 1543-1552.

(132) Bu, Z.; Wang, J.; Yu, W.; Li, B. Dermal exposure to phthalates in home environment: Handwipes, influencing factors and implications. Building and Environment. 2018, 133, 1-7.

(133) Morrison, G. C.; Weschler, C. J.; Bekö, G. Dermal uptake of phthalates from clothing: Comparison of model to human participant results. Indoor Air. 2017, 27, 642-649.

(134) Cao, J.; Zhang, X.; Zhang, Y. Predicting dermal exposure to gas-phase semivolatile organic compounds (SVOCs): a further study of SVOC mass transfer between clothing and skin surface lipids. Environ. Sci. Technol. 2018, 52, 4676-4683.

(135) Brasser, P.; Van Houwelingen, T. Theoretical and experimental study of vapor deposition onto a dressed body part. AIChE J. 2008, 54, 844-849.

(136) Eftekhari, A.; Morrison, G. Dermal uptake of benzophenone-3 from clothing: comparison of model to human participant results. In Proceedings of Indoor Air 2018; ISIAQ: Philadelphia, PA, 2018.

(137) Cao, J.; Weschler, C. J.; Luo, J.; Zhang, Y. $C_{\mathrm{m}}$-history method, a novel approach to simultaneously measure source and sink parameters important for estimating indoor exposures to phthalates. Environ. Sci. Technol. 2016, 50, 825-834.

(138) Eftekhari, A.; Morrison, G. C. A high throughput method for measuring cloth-air equilibrium distribution ratios for SVOCs present in indoor environments. Talanta 2018, 183, 250-257.

(139) Faulde, M. K.; Pages, F.; Uedelhoven, W. Bioactivity and laundering resistance of five commercially available, factory-treated permethrin-impregnated fabrics for the prevention of mosquito-borne diseases: the need for a standardized testing and licensing procedure. Parasitol. Res. 2016, 115, 1573-1582.

(140) Morrison, G. C.; Bekö, G.; Weschler, C. J. Dermal uptake from clothing of SVOCs not removed by laundering. In Proceedings of Indoor Air 2018; ISIAQ: Philadelphia, PA, 2018.

(141) Licina, D.; Melikov, A.; Sekhar, C.; Tham, K. W. Transport of gaseous pollutants by convective boundary layer around a human body. Science and Technology for the Built Environment. 2015, 21, $1175-1186$

(142) Rim, D.; Novoselec, A.; Morrison, G. The influence of chemical interactions at the human surface on breathing zone levels of reactants and products. Indoor Air 2009, 19, 324-334.

(143) Rim, D.; Gall, E. T.; Ananth, S.; Won, Y. Ozone reaction with human surfaces: Influences of surface reaction probability and indoor air flow condition. Building and Environment. 2018, 130, 40-48.

(144) Oomen, A. G.; Rompelberg, C. J. M.; Bruil, M. A.; Dobbe, C. J. G.; Pereboom, D. P. K. H.; Sips, A. J. A. M. Development of an in vitro digestion model for estimating the bioaccessibility of soil contaminants. Arch. Environ. Contam. Toxicol. 2003, 44, 281-287.

(145) Oomen, A. G.; Versantvoort, C. H. M.; Duits, M. R.; Van de Kamp, E.; Van Twillert, K. Application of in Vitro Digestion Models to Assess Release of Lead and Phthalate from Toy Matrices and Azo Dyes from Textile. RIVM report 320102003/2004; RIVM: Bilthoven, NL, 2004.

(146) Stefaniak, A. B.; Duling, M. G.; Lawrence, R. B.; Thomas, T. A.; LeBouf, R. F.; Wade, E. E.; Virji, M. A. Dermal exposure potential from textiles that contain silver nanoparticles. Int. J. Occup. Environ. Health 2014, 20, 220-234.

(147) Tovey, E. R.; Mahmic, A.; McDonald, L. G. Clothing - an important source of mite allergen exposure. J. Allergy Clin. Immunol. 1995, 96, 999-1001.

(148) D’Amato, G.; Liccardi, G.; Russo, M.; Barber, D.; D’Amato, M.; Carreira, J. Clothing is a carrier of cat allergens. J. Allergy Clin. Immunol. 1997, 99, 577-578.

(149) De Lucca, S. D.; O’Meara, T. J.; Tovey, E. R. Exposure to mite and cat allergens on a range of clothing items at home and the transfer of cat allergen in the workplace. J. Allergy Clin. Immunol. 2000, 106, 874-879.

(150) Enberg, R. N.; Shamie, S. M.; McCullough, J.; Ownby, D. R. Ubiquitous presence of cat allergen in cat-free buildings: probable dispersal from human clothing. Annals of Allergy. 1993, 70, 471-474.

(151) Almqvist, C.; Wickman, M.; Perfetti, L.; Berglind, N.; Renström, A.; Hedrén, M.; Larsson, K.; Hedlin, G.; Malmberg, P. Worsening of asthma in children allergic to cats, after indirect exposure to cat at school. Am. J. Respir. Crit. Care Med. 2001, 163, 694-698.

(152) Ritz, B. R.; Hoelscher, B.; Frye, C.; Meyer, I.; Heinrich, J. Allergic sensitization owing to 'second-hand' cat exposure in schools. Allergy 2002, 57, 357-361.

(153) Patchett, K.; Lewis, S.; Crane, J.; Fitzharris, P. Cat allergen (Fel d 1) levels on school children's clothing and in primary school classrooms in Wellington, New Zealand. J. Allergy Clin. Immunol. $1997,100,755-759$.

(154) Berge, M.; Munir, A. K.; Dreborg, S. Concentrations of cat (Fel d 1), dog (Can f 1$)$ and mite (Der f 1 and Der $\mathrm{p} 1$ ) allergens in the clothing and school environment of Swedish schoolchildren with and without pets at home. Pediatr. Allergy Immunol. 1998, 9, 25-30.

(155) Almqvist, C.; Larsson, P. H.; Egmar, A.-C.; Hedrén, M.; Malmberg, P.; Wickman, M. School as a risk environment for children allergic to cats and a site for transfer of cat allergen to homes. J. Allergy Clin. Immunol. 1999, 103, 1012-1017. 
(156) Karlsson, A.-S.; Andersson, B.; Renström, A.; Svedmyr, J.; Larsson, K.; Borres, M. P. Airborne cat allergen reduction in classrooms that use special school clothing or ban pet ownership. J. Allergy Clin. Immunol. 2004, 113, 1172-1177.

(157) Siebers, R. W.; Patchett, K.; Fitzharris, P.; Crane, J. Mite allergen (Der p 1) on children's clothing. J. Allergy Clin. Immunol. 1996, 98, 853-854.

(158) Zavada, M. S.; McGraw, S. M.; Miller, M. A. The role of clothing fabrics as passive pollen collectors in the north-eastern United States. Grana. 2007, 46, 285-291.

(159) Takahashi, Y.; Takano, K.; Suzuki, M.; Nagai, S.; Yokosuka, M.; Takeshita, T.; Saito, A.; Yasueda, H.; Enomoto, T. Two routes for pollen entering indoors: ventilation and clothes. Journal of Investigational Allergology and Clinical Immunology. 2008, 18, 382-388.

(160) Jantunen, J.; Saarinen, K. Pollen transport by clothes. Aerobiologia. 2011, 27, 339-343.

(161) Saloojee, H.; Steenhoff, A. The health professional's role in preventing nosocomial infections. Postgrad. Med. J. 2001, 77, 16-19.

(162) Oliveira, A. C.; Silva, M. D. M.; Garbaccio, J. L. Clothing of health care professional as potential reservoirs of micro-organisms: an integrative review. Texto Contexto-Enferm. 2012, 21, 684-691.

(163) Wong, D.; Nye, K.; Hollis, P. Microbial flora on doctors' white coats. British Medical Journal. 1991, 303, 1602-1604.

(164) Treakle, A. M.; Thom, K. A.; Furuno, J. P.; Strauss, S. M.; Harris, A. D.; Perencevich, E. N. Bacterial contamination of health care workers' white coats. Am. J. Infect. Control 2009, 37, 101-105.

(165) Wiener-Well, Y.; Galuty, M.; Rudensky, B.; Schlesinger, Y.; Attias, D.; Yinnon, A. M. Nursing and physician attire as possible source of nosocomial infections. Am. J. Infect. Control 2011, 39, 555559.

(166) Biljan, M. M.; Hart, C. A.; Sunderland, D.; Manasse, P. R.; Kingsland, C. R. Multicentre randomized double bind crossover trial on contamination of conventional ties and bow ties in routine obstetric and gynaecological practice. British Medical Journal. 1993, 307, 1582-1584.

(167) Lopez, P.-J.; Ron, O.; Parthasarathy, P.; Soothill, J.; Spitz, L. Bacterial counts from hospital doctors' ties are higher than those from shirts. Am. J. Infect. Control 2009, 37, 79-80.

(168) Snyder, G. M.; Thom, K. A.; Furuno, J. P.; Perencevich, E. N.; Roghmann, M.-C.; Strauss, S. M.; Netzer, G.; Harris, A. D. Detection of methicillin-resistant Staphylococcus aureus and vancomycin-resistant enterococci on the gowns and gloves of healthcare workers. Infection Control and Hospital Epidemiology. 2008, 29, 583-589.

(169) Babb, J. R.; Davies, J. G.; Ayliffe, G. A. J. Contamination of protective clothing and nurses' uniforms in an isolation ward. Journal of Hospital Infection. 1983, 4, 149-157.

(170) Perry, C.; Marshall, R.; Jones, E. Bacterial contamination of uniforms. Journal of Hospital Infection. 2001, 48, 238-241.

(171) Loh, W.; Ng, V. V.; Holton, J. Bacterial flora on the white coats of medical students. Journal of Hospital Infection. 2000, 45, 6568.

(172) Scott, E.; Goodyear, N.; Nicoloro, J. M.; Marika, D. J.; Killion, E.; Duty, S. M. Laundering habits of student nurses and correlation with the presence of Staphylococcus aureus on nursing scrub tops preand postlaundering. Am. J. Infect. Control 2015, 43, 1006-1008.

(173) Bisaga, A.; Paquette, K.; Sabatini, L.; Lovell, E. O. A prevalence study of methicillin-resistant Staphylococcus aureus colonization in emergency department health care workers. Annals of Emergency Medicine. 2008, 52, 525-528.

(174) Ibarra, M.; Flatt, T.; Van Maele, D.; Ahmed, A.; Fergie, J.; Purcell, K. Prevalence of methicillin-resistant Staphylococcus aureus nasal carriage in healthcare workers. Pediatric Infectious Disease Journal. 2008, 27, 1109-1111.

(175) Gaspard, P.; Eschbach, E.; Gunther, D.; Gayet, S.; Bertrand, X.; Talon, D. Meticillin-resistant Staphylococcus aureus contamination of healthcare workers' uniforms in long-term care facilities. Journal of Hospital Infection. 2009, 71, 170-175.
(176) Sanon, M.-A.; Watkins, S. Nurses uniforms: How many bacteria do they carry after one shift? Journal of Public Health and Epidemiology. 2012, 4, 311-315.

(177) Homaira, N.; Sheils, J.; Stelzer-Braid, S.; Lui, K.; Oie, J.-L.; Snelling, T.; Jaffe, A.; Rawlinson, W. Respiratory syncytial virus is present in the neonatal intensive care unit. J. Med. Virol. 2016, 88, 196-201.

(178) Doig, C. M. The effect of clothing on the dissemination of bacteria in operating theaters. Br. J. Surg. 1972, 59, 878-881.

(179) Whyte, W.; Vesley, D.; Hodgson, R. Bacterial dispersion from operating room clothing. J. Hyg. 1976, 76, 367-378.

(180) Hambraeus, A. Dispersal and transfer of Staphylococcus aureus in an isolation ward for burned patients. J. Hyg. 1973, 71, 787-797.

(181) Handorean, A.; Robertson, C. E.; Harris, J. K.; Frank, D.; Hull, N.; Kotter, C.; Stevens, M. J.; Baumgardner, D.; Pace, N. R.; Hernandez, M. Microbial aerosol liberation from soiled textiles isolated during routine residuals handling in a modern health care setting. Microbiome. 2015, 3, 72.

(182) Duguid, J. P.; Wallace, A. T. Air infection with dust liberated from clothing. Lancet 1948, 252, 845-849.

(183) Hambraeus, A. Transfer of Staphylococcus aureus via nurses' uniforms. J. Hyg. 1973, 71, 799-814.

(184) Hill, J.; Howell, A.; Blowers, R. Effect of clothing on dispersal of Staphylococcus aureus by males and females. Lancet 1974, 304, $1131-1133$

(185) Dastjerdi, R.; Montazer, M. A review on the application of inorganic nano-structured materials in the modification of textiles: focus on anti-microbial properties. Colloids Surf., B 2010, 79, 5-18.

(186) Savolainen, K.; Pylkkänen, L.; Norppa, H.; Falck, G.; Lindberg, H.; Tuomi, T.; Vippola, M.; Alenius, H.; Hämeri, K.; Koivisto, J.; Brouwer, D.; Mark, D.; Bard, D.; Berges, M.; Jankowska, E.; Posniak, M.; Farmer, P.; Singh, R.; Krombach, F.; Bihari, P.; Kasper, G.; Seipenbusch, M. Nanotechnologies, engineered nanomaterials and occupational health and safety $-\mathrm{A}$ review. Safety Science. 2010, 48, 957-963.

(187) Kulthong, K.; Srisung, S.; Boonpavanitchakul, K.; Kangwansupamonkon, W.; Maniratanachote, R. Determination of silver nanoparticle release from antibacterial fabrics into artificial sweat. Part. Fibre Toxicol. 2010, 7, 8.

(188) Von Goetz, N.; Lorenz, C.; Windler, L.; Nowack, B.; Heuberger, M.; Hungerbühler, K. Migration of Ag- and $\mathrm{TiO}_{2^{-}}$ (nano)particles from textiles into artificial sweat under physical stress: Experiments and exposure modeling. Environ. Sci. Technol. 2013, 47, 9979-9987.

(189) Benn, T. M.; Westerhoff, P. Nanoparticle silver released into water from commercially available sock fabrics. Environ. Sci. Technol. 2008, 42, 4133-4139.

(190) Geranio, L.; Heuberger, M.; Nowack, B. The behavior of silver nanotextiles during washing. Environ. Sci. Technol. 2009, 43, 81138118.

(191) Burden, M.; Keniston, A.; Frank, M. G.; Brown, C. A.; Zoucha, J.; Cervantes, L.; Weed, D.; Boyle, K.; Price, C.; Albert, R. K. Bacterial contamination of healthcare workers' uniforms: A randomized controlled trial of antimicrobial scrubs. Journal of Hospital Medicine. 2013, 8, 380-385.

(192) Nohynek, G. J.; Lademann, J.; Ribaud, C.; Roberts, M. S. Grey goo on the skin? Nanotechnology, cosmetic and sunscreen safety. Crit. Rev. Toxicol. 2007, 37, 251-277.

(193) Gulson, B.; Wong, H.; Korsch, M.; Gomez, L.; Casey, P.; McCall, M.; McCulloch, M.; Trotter, J.; Stauber, J.; Greenoak, G. Comparison of dermal absorption of zinc from different sunscreen formulations and differing UV exposure based on stable isotope tracing. Sci. Total Environ. 2012, 420, 313-318.

(194) Larese Filon, F.; Mauro, M.; Adami, G.; Bovenzi, M.; Crosera, M. Nanoparticles skin absorption: new aspects for a safety profile evaluation. Regul. Toxicol. Pharmacol. 2015, 72, 310-322.

(195) Donovan, E. P.; Donovan, B. L.; McKinley, M. A.; Cowan, D. M.; Paustenbach, D. J. Evaluation of take home (paraoccupational) 
exposure to asbestos and disease: A review of the literature. Crit. Rev. Toxicol. 2012, 42, 703-731.

(196) Goswami, E.; Craven, V.; Dahlstrom, D. L.; Alexander, D.; Mowat, F. Domestic asbestos exposure: A review of epidemiologic and exposure data. Int. J. Environ. Res. Public Health 2013, 10, 56295670.

(197) Sahmel, J.; Barlow, C. A.; Simmons, B.; Gaffney, S. H.; Avens, H. J.; Madl, A. K.; Henshaw, J.; Lee, R. J.; Van Orden, D.; Sanchez, M.; Zock, M.; Paustenbach, D. J. Evaluation of take-home exposure and risk associated with the handling of clothing contaminated with chrysotile asbestos. Risk Analysis. 2014, 34, 1448-1468.

(198) Meadow, J. F.; Altrichter, A. E.; Bateman, A. C.; Stenson, J.; Brown, G. Z.; Green, J. L.; Bohannan, B. J. M. Humans differ in their personal microbial cloud. PeerJ 2015, 3, No. e1258.

(199) Bhangar, S.; Adams, R. I.; Pasut, W.; Huffman, J. A.; Arens, E. A.; Taylor, J. W.; Bruns, T. D.; Nazaroff, W. W. Chamber bioaerosol study: Human emissions of size-resolved fluorescent biological aerosol particles. Indoor Air. 2016, 26, 193-206.

(200) Licina, D.; Bhangar, S.; Brooks, B.; Baker, R.; Firek, B.; Tang, X.; Morowitz, M. J.; Banfield, J. F.; Nazaroff, W. W. Concentrations and sources of airborne particles in a neonatal intensive care unit. PLoS One 2016, 11, No. e0154991.

(201) Zhou, J.; Fang, W.; Cao, Q.; Yang, L.; Chang, V. W.-C.; Nazaroff, W. W. Influence of moisturizer and relative humidity on human emissions of fluorescent biological aerosol particles. Indoor Air. 2017, 27, 587-598.

(202) Licina, D.; Tian, Y.; Nazaroff, W. W. Emission rates and the personal cloud effect associated with particle release from the perihuman environment. Indoor Air. 2017, 27, 791-802.

(203) Nazaroff, W. W. Indoor particle dynamics. Indoor Air 2004, 14 (Suppl 7), 175-183.

(204) Nazaroff, W. W. Inhalation intake fraction of pollutants from episodic indoor emissions. Building and Environment. 2008, 43, 269277.

(205) Qian, J.; Peccia, J.; Ferro, A. R. Walking-induced particle resuspension in indoor environments. Atmos. Environ. 2014, 89, 464481.

(206) Licina, D.; Nazaroff, W. W. Clothing as a transport vector for airborne particles: Chamber study. Indoor Air. 2018, 28, 404-414.

(207) Bartek, M.; Verdial, F.; Dellinger, E. P. Naked surgeons? The debate about what to wear in the operating room. Clin. Infect. Dis. 2017, 65, 1589-1592.

(208) Rubbo, S. D.; Saunders, J. Liberation of organisms from contaminated textiles. J. Hyg. 1963, 61, 507-513.

(209) Clark, R. P. Skin scales among airborne particles. J. Hyg. 1974, $72,47-51$.

(210) Noble, W. C. Dispersal of skin microorganisms. Br. J. Dermatol. 1975, 93, 477-485.

(211) Noble, W. C.; Habbema, J. D. F.; Van Furth, R.; Smith, I.; De Raay, C. Quantitative studies on the dispersal of skin bacteria into the air. J. Med. Microbiol. 1976, 9, 53-61.

(212) Grice, E. A.; Segre, J. A. The skin microbiome. Nat. Rev. Microbiol. 2011, 9, 244-253.

(213) Kong, H. H. Skin microbiome: genomics-based insights into the diversity and role of skin microbes. Trends Mol. Med. 2011, 17, $320-328$.

(214) Findley, K.; Oh, J.; Yang, J.; Conlan, S.; Deming, C.; Meyer, J. A.; Schoenfeld, D.; Nomicos, E.; Park, M.; NIH Intramural Sequencing Center Comparative Sequencing Program; Kong, H. H.; Segre, J. A. Topographic diversity of fungal and bacterial communities in human skin. Nature 2013, 498, 367-370.

(215) Neely, A. N.; Orloff, M. M. Survival of some medically important fungi on hospital fabrics and plastics. Journal of Clinical Microbiology. 2001, 39, 3360-3361.

(216) Adams, R. I.; Bhangar, S.; Pasut, W.; Arens, E. A.; Taylor, J. W.; Lindow, S. E.; Nazaroff, W. W.; Bruns, T. D. Chamber bioaerosol study: Outdoor air and human occupants as sources of indoor airborne microbes. PLoS One 2015, 10, No. e0128022.
(217) Nam, H.-S.; Crane, J.; Siebers, R. Clothing-potentially a significant source of endotoxin exposure. J. Allergy Clin. Immunol. 2003, 112, 624-625.

(218) Mackintosh, C. A.; Hoffman, P. N. An extended model for transfer of micro-organisms via the hands: differences between organisms and the effect of alcohol disinfection. J. Hyg. 1984, 92, $345-355$.

(219) Sattar, S. A.; Springthorpe, S.; Mani, S.; Gallant, M.; Nair, R. C.; Scott, E.; Kain, J. Transfer of bacteria from fabrics to hands and other fabrics: development and application of a quantitative method using Staphylococcus aureus as a model. J. Appl. Microbiol. 2001, 90, 962-970.

(220) You, R.; Cui, W.; Chen, C.; Zhao, B. Measuring the shortterm emission rates of particles in the "personal cloud" with different clothes and activity intensities in a sealed chamber. Aerosol Air Qual. Res. 2013, 13, 911-921.

(221) Bethune, D. W.; Blowers, R; Parker, M.; Pask, E. A. Dispersal of Staphylococcus aureus by patients and surgical staff. Lancet 1965, 285, 480-483.

(222) Mackintosh, C. A.; Lidwell, O. M.; Towers, A. G.; Marples, R. $\mathrm{R}$. The dimensions of skin fragments dispersed into the air during activity. J. Hyg. 1978, 81, 471-479.

(223) Hall, G. S.; Mackintosh, C. A.; Hoffman, P. N. The dispersal of bacteria and skin scales from the body after showering and after application of a skin lotion. J. Hyg. 1986, 97, 289-298.

(224) Whyte, W.; Hejab, M. Particle and microbial airborne dispersion from people. European Journal of Parenteral and Pharmaceutical Sciences. 2007, 12, 39-46.

(225) Bernard, H. R.; Speers, R. Jr.; O'Grady, F. W.; Shooter, R. A. Airborne bacterial contamination: Investigation of human sources. Arch. Surg. 1965, 91, 530-533.

(226) Speers, R. Jr.; Bernard, H.; O’Grady, F.; Shooter, R. A. Increased dispersal of skin bacteria into the air after shower-baths. Lancet 1965, 285, 478-480.

(227) Cleton, F. J.; Van der Mark, Y. S.; Van Toorn, M. J. Effect of shower-bathing on dispersal of recently acquired transient skin flora. Lancet 1968, 291, 865 .

(228) Lidwell, O. M.; Mackintosh, C. A.; Towers, A. G. The evaluation of fabrics in relation to their use as protective garments in nursing and surgery. II. Dispersal of skin organisms in a test chamber. J. Hyg. 1978, 81, 453-469.

(229) Qian, J.; Hospodsky, D.; Yamamoto, N.; Nazaroff, W. W.; Peccia, J. Size-resolved emission rates of airborne bacteria and fungi in an occupied classroom. Indoor Air. 2012, 22, 339-351.

(230) Bhangar, S.; Huffman, J. A.; Nazaroff, W. W. Size-resolved fluorescent biological aerosol particle concentrations and occupant emissions in a university classroom. Indoor Air. 2014, 24, 604-617.

(231) Mbithi, J. N.; Springthorpe, V. S.; Sattar, S. A. Effect of relative humidity and air temperature on survival of hepatitis A virus on environmental surfaces. Appl. Environ. Microbiol. 1991, 57, 13941399.

(232) Tang, J. W. The effect of environmental parameters on the survival of airborne infectious agents. J. R. Soc. Interface 2009, 6, S737-S746.

(233) Wilkoff, L. J.; Westbrook, L.; Dixon, G. J. Persistence of Salmonella typhimurium on fabrics. Appl. Microbiol. 1969, 18, 256261.

(234) Neely, A. N.; Maley, M. P. Survival of enterococci and staphylococci on hospital fabrics and plastic. Journal of Clinical Microbiology. 2000, 38, 724-6.

(235) Sidwell, R. W.; Dixon, G. J.; McNeil, E. Quantitative studies on fabrics as disseminators of viruses. I. Persistence of vaccinia virus on cotton and wool fabrics. Appl. Microbiol. 1966, 14, 55-59.

(236) Wilkoff, L. J.; Westbrook, L.; Dixon, G. J. Factors affecting the persistence of Staphylococcus aureus on fabrics. Appl. Microbiol. 1969, $17,268-274$

(237) Neely, A. N. A survey of Gram-negative bacteria survival on hospital fabrics and plastics. J. Burn Care Rehabil. 2000, 21, 523-527. 
(238) Callewaert, C.; Van Nevel, S.; Kerckhof, F.-M.; Granitsiotis, M. S.; Boon, N. Bacterial exchange in household washing machines. Front. Microbiol. 2015, 6, 1381.

(239) Nordstrom, J. M.; Reynolds, K. A.; Gerba, C. P. Comparison of bacteria on new, disposable, laundered, and unlaundered hospital scrubs. Am. J. Infect. Control 2012, 40, 539-543.

(240) Lakdawala, N.; Pham, J.; Shah, M.; Holton, J. Effectiveness of low-temperature domestic laundry on the decontamination of healthcare workers' uniforms. Infection Control and Hospital Epidemiology. 2011, 32, 1103-1108.

(241) Christian, R. R.; Manchester, J. T.; Mellor, M. T. Bacteriological quality of fabrics washed at lower-than-standard temperatures in a hospital laundry facility. Appl. Environ. Microbiol. 1983, 45, 591-597.

(242) Gerba, C. P.; Kennedy, D. Enteric virus survival during household laundering and impact of disinfection with sodium hypochlorite. Appl. Environ. Microbiol. 2007, 73, 4425-4428.

(243) Vikke, H. S.; Giebner, M. UniStatus - a cross-sectional study on the contamination of uniforms in the Danish ambulance service. BMC Res. Notes 2015, 8, 95.

(244) Terpstra, P. M. J. Domestic and institutional hygiene in relation to sustainability. Historical, social and environmental implications. Int. Biodeterior. Biodegrad. 1998, 41, 169-175.

(245) Munk, S.; Johansen, C.; Stahnke, S. H.; Adler-Nissen, J. Microbial survival and odor in laundry. J. Surfactants Deterg. 2001, 4, 385-394.

(246) Laitala, K.; Jensen, H. M. Cleaning effect of household laundry detergents at low temperatures. Tenside, Surfactants, Deterg. 2010, 47, 413-420.

(247) Adams, R. I.; Miletto, M.; Taylor, J. W.; Bruns, T. D. The diversity and distribution of fungi on residential surfaces. PLoS One 2013, 8, No. e78866.

(248) Noble, R. E. Environmental tobacco smoke uptake by clothing fabrics. Sci. Total Environ. 2000, 262, 1-3.

(249) Liljegren, J. C.; Brown, D. F.; Lunden, M. M.; Silcott, D. Particle deposition onto people in a transit venue. Health Security. 2016, 14, 237-249.

(250) Hammer, T. R.; Mucha, H.; Hoefer, D. Infection risk by dermatophytes during storage and after domestic laundry and their temperature-dependent inactivation. Mycopathologia 2011, 171, 4349.

(251) McDonagh, A.; Sextro, R. G.; Byrne, M. A. Mass transport of deposited particles by surface-to-surface contact. J. Hazard. Mater. 2012, 227-228, 370-377.

(252) Clarke, D.; Burke, D.; Gormally, M.; Byrne, M. Dynamics of house dust mite transfer in modern clothing fabrics. Ann. Allergy, Asthma, Immunol. 2015, 114, 335-340.

(253) Nazaroff, W. W.; Cass, G. R. Mass-transport aspects of pollutant removal at indoor surfaces. Environ. Int. 1989, 15, 567-584.

(254) Fogh, C. L.; Byrne, M. A.; Andersson, K. G.; Bell, K. F.; Roed, J.; Goddard, A. J. H.; Vollmair, D. V.; Hotchkiss, S. A. M. Quantitative measurement of aerosol deposition on skin, hair and clothing for dosimetric assessment. Risø-R-1075; Risø National Laboratory: Roskilde, 1999.

(255) McDonagh, A.; Byrne, M. A. A study of the size distribution of aerosol particles resuspended from clothing surfaces. J. Aerosol Sci. 2014, 75, 94-103.

(256) Wang, J.; Niu, L.; Zhang, T.; Wang, S. Detachment of adhered particles from a cloth surface subjected to arod strike. Aerosol Sci. Technol. 2019, 53, 435-448.

(257) Yoon, Y. H.; Brimblecombe, P. Clothing as a source of fibres within museums. Journal of Cultural Heritage. 2000, 1, 445-454.

(258) McDonagh, A.; Byrne, M. A. The influence of human physical activity and contaminated clothing type on particle resuspension. $J$. Environ. Radioact. 2014, 127, 119-126.

(259) Cohen, B. S.; Positano, R. Resuspension of dust from work clothing as a source of inhalation exposure. Am. Ind. Hyg. Assoc. J. 1986, 47, 255-258.
(260) Textile Outlook International. World textile and apparel trade and production trends 2017, 188, 10-19. 